Bedankt voor het downloaden van dit artikel. De artikelen uit de (online)tijdschriften van Uitgeverij Boom zijn auteursrechtelijk beschermd. U kunt er natuurlijk uit citeren (voorzien van een bronvermelding) maar voor reproductie in welke vorm dan ook moet toestemming aan de uitgever worden gevraagd.

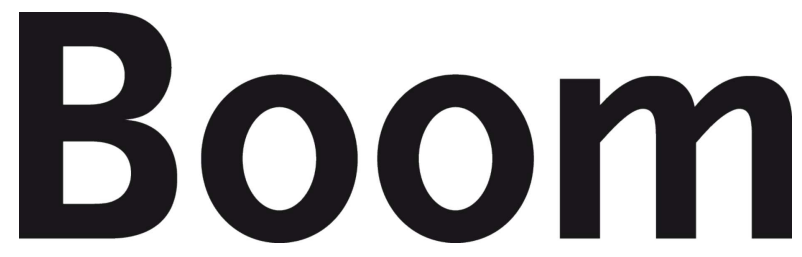

Behoudens de in of krachtens de Auteurswet van 1912 gestelde uitzonderingen mag niets uit deze uitgave worden verveelvoudigd, opgeslagen in een geautomatiseerd gegevensbestand, of openbaar gemaakt, in enige vorm of op enige wijze, hetzij elektronisch, mechanisch door fotokopieën, opnamen of enig andere manier, zonder voorafgaande schriftelijke toestemming van de uitgever.

Voor zover het maken van kopieën uit deze uitgave is toegestaan op grond van artikelen $16 \mathrm{~h} \mathrm{t} / \mathrm{m} 16 \mathrm{~m}$ Auteurswet 1912 jo. Besluit van 27 november 2002, Stb 575, dient men de daarvoor wettelijk verschuldigde vergoeding te voldoen aan de Stichting Reprorecht te Hoofddorp (postbus 3060, 2130 $\mathrm{KB}$, www.reprorecht.nl) of contact op te nemen met de uitgever voor het treffen van een rechtstreekse regeling in de zin van art. 16l, vijfde lid, Auteurswet 1912.

Voor het overnemen van gedeelte(n) uit deze uitgave in bloemlezingen, readers en andere

compilatiewerken (artikel 16, Auteurswet 1912) kan men zich wenden tot de Stichting PRO (Stichting Publicatie- en Reproductierechten, postbus 3060, 2130 KB Hoofddorp, www.cedar.nl/pro).

No part of this book may be reproduced in any way whatsoever without the written permission of the publisher.

info@boomamsterdam.nl

www.boomuitgeversamsterdam.nl 


\title{
Stigma's van minder flexibiliteit en minder technologische kennis verlagen jobkansen voor 50-plussers
}

\author{
Hannah van Borm \& Stijn Baert*
}

\begin{abstract}
Onderzoek heeft aangetoond dat discriminatie in het wervings- en selectieproces ten aanzien van oudere kandidaten die solliciteren voor een baan (jobkandidaten), een groot probleem is in België. Over de redenen voor deze discriminatie is echter nog weinig bekend. In deze studie presenteren we een vignettenexperiment uitgevoerd bij 193 Vlaamse HR-professionals om na te gaan welke stereotypen en attituden ten aanzien van oudere jobkandidaten leeftijdsdiscriminatie in werving en selectie verklaren. Elke participant beoordeelde vijf fictieve jobkandidaten op een aantal kenmerken. Dit resulteerde in 965 sets met observaties. De resultaten laten zien dat recruiters een oudere leeftijd op een cv associëren met lagere fysieke capaciteiten, minder technologische knowhow, een lagere flexibiliteit, een lagere trainbaarheid en een hogere mate van betrouwbaarheid. Daarnaast vermoeden recruiters dat andere werknemers minder graag zullen samenwerken met oudere jobkandidaten. Van deze verschillende leeftijdssignalen fungeren de percepties omtrent flexibiliteit en technologische knowhow als voornaamste verklaringen voor het negatieve effect van iemands leeftijd op diens tewerkstellingskansen. Bovendien vinden we dat leeftijdsdiscriminatie sterker is in beroepen die worden geassocieerd met hoge fysieke inspanning. Deze studie is maatschappelijk relevant daar de effectiviteit van antidiscriminatiebeleid afhangt van de mate waarin dit beleid inspeelt op de mechanismen en moderatoren onderliggend aan discriminatie.
\end{abstract}

\section{Introductie}

De financiering van het socialezekerheidssysteem in België is de voorbije decennia steeds meer onder druk komen te staan. De vergrijzing van de Belgische populatie, alsook de lage werkzaamheidsgraad van 50-plussers liggen aan de basis hiervan (Baert, Norga, Thuy, \& Van Hecke, 2016; De Callatay \& Turtelboom, 1996; Pestieau \& Stijns, 1999). Om deze problematiek aan te pakken heeft de Belgische overheid de voorbije jaren getracht de werkzaamheidsgraad van $55^{-}$tot 64 -jarigen te doen stijgen door het brugpensioen af te bouwen en de pensioenleeftijd op te trekken (Federale Pensioendienst, 2019). Ondanks het feit dat de werkzaamheidsgraad onder de 55- tot 64-jarigen de afgelopen jaren is gestegen (d.w.z. van $42.4 \%$ in 2014 naar $50.4 \%$ in 2018), blijft de achterstand in vergelijking met onze buurlanden groot.

* Hannah van Borm \& Stijn Baert zijn verbonden aan de Universiteit Gent, Vakgroep Economie. Correspondentieadres: Hannah van Borm, Vakgroep Economie, Sint-Pietersplein 6, B-9000 Gent, e-mail: hannah.vanborm@ugent.be. 
Daar waar slechts de helft van alle 55- tot 64-jarigen in België werkt, is dit gemiddeld $59.2 \%$ in Europa, $68.3 \%$ in Nederland en $71.7 \%$ in Duitsland (Baert, 2019).

Een mogelijke verklaring voor deze moeizame stijging in de werkzaamheidsgraad onder 55-plussers betreft het optreden van leeftijdsdiscriminatie op de Belgische arbeidsmarkt en meer precies in het wervings- en selectieproces. Een recent veldexperiment uitgevoerd in Vlaanderen, waarbij fictieve cv's werden uitgestuurd naar bestaande vacatures en waarbij de positieve reacties op deze fictieve sollicitaties werden gemeten, toont aan dat oudere jobkandidaten $39.7 \%$ lagere kansen hebben om uitgenodigd te worden voor een jobinterview (Baert et al., 2016). Ook in andere landen werd een dergelijke leeftijdsdiscriminatie in wervings- en selectieprocedures gevonden (Baert, 2018; Neumark, 2018).

Deze veldexperimenten geven weer hoeveel discriminatie er bestaat op de arbeidsmarkt. Ze kunnen ons echter niets zeggen over de achterliggende redenen voor deze discriminatie. Om leeftijdsdiscriminatie in het wervings- en selectieproces aan te pakken, is het echter belangrijk om meer inzicht te verwerven in de mechanismen die deze discriminatie drijven.

In de economische literatuur worden twee theoretische verklaringen aangehaald. De eerste verklaring kan worden gevonden in Arrow's (1973) model van statistische discriminatie. Dit model stelt dat leeftijdsdiscriminatie wordt ingegeven door verschillende (negatieve) stereotypen omtrent de productiviteit van oudere werknemers. Bij het maken van selectiebeslissingen hebben werkgevers vaak beperkte informatie ter beschikking over een jobkandidaat, zoals hun gender, leeftijd, opleidingsniveau en werkervaring. Volgens de theorie van statistische discriminatie zullen zij deze beperkte informatie gebruiken als signaal voor andere niet-geobserveerde karakteristieken. Zo kan een hogere leeftijd op iemands $\mathrm{cv}$ geassocieerd worden met een lagere flexibiliteit (AARP, 2000; Büsch, Dahl, \& Dittrich, 2009; McCann \& Keaton, 2013; Warr \& Pennington, 1993). De tweede klassieke verklaring voor leeftijdsdiscriminatie wordt gegeven door het model van voorkeursdiscriminatie (Becker, 1957). Dit model stelt dat leeftijdsdiscriminatie gedreven wordt door negatieve attituden die werkgevers kunnen hebben jegens samenwerken met oudere werknemers ('werkgeversdiscriminatie') of de angst van werkgevers dat andere werknemers of klanten niet graag interacteren met oudere werknemers ('werknemersdiscriminatie' of 'klantendiscriminatie'; Baert \& De Pauw, 2014).

Voor zover wij weten, bestaat er nog geen onderzoek dat ingaat op verklaringen voor leeftijdsdiscriminatie in het selectieproces in België en meer precies in Vlaanderen. Met deze studie willen we deze 'black box' in de literatuur invullen door na te gaan waarom Vlaamse werkgevers discrimineren jegens 50-plussers in het wervings- en selectieproces (d.w.z. de drijfveren van leeftijdsdiscriminatie) en in welke situaties deze discriminatie hoger of lager is (d.w.z. de moderatoren van leeftijdsdiscriminatie). We doen dit aan de hand van een vignettenexperiment uitgevoerd bij 193 Vlaamse wervingsprofessionals.

Dit onderzoek vormt de voorstudie op Van Borm, Burn en Baert (2019), waarin we op grotere, internationale schaal een gelijksoortig experiment uitvoerden bij (voornamelijk) Amerikaanse individuen die ervaren waren in het werven van jobkandidaten en gerekruteerd werden via het online platform Amazon Mechanical Turk. Door het huidige experiment tevens uit te voeren in een meer internationale 
context zijn we in staat om na te gaan of de resultaten van dit onderzoek gerepliceerd kunnen worden in andere contexten.

\section{Methode}

\subsection{Vignettendesign}

Om onze onderzoeksvragen te beantwoorden voerden we, net zoals Van Borm et al. (2019), een vignettenexperiment uit. Dit type experiment wordt in de wetenschappelijke literatuur vaak gebruikt om menselijke beoordelingen en overtuigingen te bestuderen (Auspurg \& Hinz, 2014; Jasso, 2006; Rossi \& Nock, 1982). Concreet wordt aan participanten gevraagd om een serie beoordelingen te maken gebaseerd op een set fictieve beschrijvingen (d.w.z. vignetten). Bij het bestuderen van selectiebeslissingen bestaan vignetten doorgaans uit cv's van fictieve jobkandidaten of een tabelmatige samenvatting van kandidaatsprofielen (bijv. Van Belle, Di Stasio, Caers, De Couck, \& Baert, 2018; Van Belle et al., 2020; Van Borm \& Baert, 2018; Van Borm, Dhoop, Van Acker, \& Baert, 2020), waarbij de karakteristieken van een kandidaat (d.w.z. de vignettenfactoren) systematisch of random variëren over een bepaald aantal categorieën (d.w.z. de vignettenniveaus) (Sauer, Hinz, Auspurg, \& Liebig, 2011).

Specifiek voor deze studie dienden de Vlaamse HR-professionals die deelnamen aan ons experiment zich in te leven in de rol van recruiter voor een hypothetisch bedrijf en moesten zij elk vijf fictieve profielen van jobkandidaten beoordelen met het oog op het invullen van een bepaalde hypothetische vacature. De profielen verschilden in vijf karakteristieken, die op hun beurt systematisch varieerden over 2 tot 32 categorieën. Meer bepaald betrof het (1) het geslacht (d.w.z. man, vrouw), (2) de leeftijd (d.w.z. 32, 33, 34, 35, 36, ..., 63), (3) de afstand tussen woonplaats en plaats van tewerkstelling (d.w.z. O-5 km, 5-10 km, 10-50 km, meer dan $50 \mathrm{~km}$ ), (4) de ervaring in het beroep (d.w.z. geen, ongeveer 2 jaar, ongeveer 5 jaar, ongeveer 10 jaar) en (5) de extra-curriculaire activiteiten (d.w.z. geen, vrijwilligerswerk, sportactiviteiten, culturele activiteiten) van de jobkandidaten, waarbij leeftijd de belangrijkste factor was voor ons experiment. We kozen ervoor de profielen, naast de leeftijd van de kandidaten, ook te laten variëren over deze vier andere karakteristieken om de aard van echte selectiebeslissingen zo goed mogelijk na te bootsen en het hoofddoel van het onderzoek niet te expliciet te maken om zo sociaal wenselijke antwoorden te vermijden. Al de factoren en hun bijhorende niveaus werden geselecteerd op basis van een kritische lezing van de relevante literatuur (Carlsson \& Eriksson, 2019; Carlsson, Reshid, \& Rooth, 2018; Nuijten, Poell, \& Alfes, 2017; Olian, Schwab, \& Haberfeld, 1988; Richardson, Webb, Webber, \& Smith, 2013) en werden zodanig gekozen dat onlogische combinaties van vignettenfactoren niet voorkwamen (Auspurg \& Hinz, 2014). Een overzicht van de vignettenfactoren en niveaus is te vinden in Tabel A.1 in de Bijlagen.

Het kruisen van de verschillende vignettenniveaus voor de vijf vignettenfactoren resulteerde in principe in 4096 (d.w.z. 2 × 32 x 4 x 4 x 4) mogelijke combinaties van kandidaat-karakteristieken (d.w.z. fictieve profielen of vignetten). Omdat we beoogden elk vignet minstens vijf keer te laten beoordelen, zoals aangeraden door 
Auspurg en Hinz (2014), was het niet mogelijk alle 4096 vignetten te laten evalueren, aangezien dit een enorme steekproef zou vereisen of ervoor zou zorgen dat elke participant in het experiment een groot aantal vignetten zou moeten evalueren, wat zou kunnen leiden tot vermoeidheid en bijgevolg data van een lagere kwaliteit zou kunnen opleveren (Auspurg \& Hinz, 2014). Om dit probleem op te lossen besloten we een steekproef te trekken uit deze pool van fictieve profielen aan de hand van een D-efficiënt design. Dit design is een algoritme ontwikkeld door Kuhfeld, Tobias en Garratt (1994) en beschreven door Auspurg en Hinz (2014), dat die combinaties van vignettenniveaus selecteert met de hoogste statistische kracht. Door te werken met een D-efficiënt design waren we in staat een meer efficiënt experimenteel design te realiseren, waarvoor minder vignettenbeoordelingen nodig zijn om een zelfde hoeveelheid aan statistische kracht en informatie te krijgen dan een minder efficiënt design. In totaal selecteerden we 200 verschillende profielen volgens de procedure beschreven in Auspurg en Hinz (2014). De D-efficiëntie van ons design was hoog en bedroeg 99.11. ${ }^{1}$ Nadat de 200 profielen geselecteerd waren, gebruikten we hetzelfde algoritme om de profielen systematisch te groeperen in 40 blokken van vijf profielen (d.w.z. een deck). De 40 decks werden vervolgens lukraak (random) toegewezen aan de participanten op zo'n manier dat elk deck ongeveer even vaak voorgelegd werd aan de participanten. De volgorde waarin de verschillende profielen gepresenteerd werden aan de participanten binnen een deck, varieerde daarenboven ook op een lukrake (random) manier.

Het grote voordeel van deze aanpak is dat we door de experimentele manipulatie van de verschillende karakteristieken en bijhorende categorieën de samenhang tussen de verschillende karakteristieken minimaliseren. Hierdoor zijn we in staat het afzonderlijke effect van elk van de karakteristieken, waaronder in het bijzonder de leeftijd van de fictieve jobkandidaat, op een bepaalde uitkomstvariabele te identificeren en onze resultaten een causale interpretatie te geven.

\subsection{Experimenteel materiaal}

Het experiment werd geïmplementeerd in een Nederlandstalige online survey. In deze online survey dienden de participanten (d.w.z. Vlaamse HR-professionals), zoals aangehaald, zich eerst in te leven in de rol van recruiter voor een hypothetisch bedrijf en moesten zij aan de hand van een beoordelingsformulier elk vijf fictieve profielen van jobkandidaten beoordelen met het oog op het invullen van een bepaalde hypothetische vacature (bijv. tandtechnicus). Na het evalueren van de fictieve jobkandidaten dienden zij ook een vragenlijst in te vullen waarin zij bevraagd werden over een aantal persoonsgebonden kenmerken. Concreet bestond de online survey uit vijf verschillende elementen: (1) een korte introductie, (2) een hypothetische vacature, (3) een deck van vijf fictieve profielen van kandidaten, (4) een beoordelingsformulier per fictief profiel, en (5) een postexperimentele vragenlijst. In wat volgt, bespreken we elk van deze elementen opeenvolgend.

Het eerste element dat gepresenteerd werd aan de participanten, betrof, zoals aangehaald, een korte introductie. In deze introductie werden zij geïnformeerd omtrent (1) het doel van de studie, (2) hoelang de studie zou duren (d.w.z. onge- 
veer 15 minuten), (3) de prijzen die zij konden winnen (d.w.z. één van de 10 Bongobonnen t.w.v. $€ 30$ of één Bongo-bon t.w.v. €190), en (4) het feit dat hun antwoorden strikt anoniem en vertrouwelijk verwerkt zouden worden. Wanneer de deelnemers toestemden om deel te nemen aan het onderzoek, kregen zij toegang tot het online experiment.

Het tweede element dat de participanten te zien kregen, betrof de hypothetische vacature. In totaal boden we acht verschillende vacatures aan van jobs uit uiteenlopende sectoren die varieerden wat betreft (1) de algemene vaardigheden, (2) het contact met klanten, (3) de fysieke inspanningen en (4) de technologische knowhow die nodig is om de job naar behoren uit te oefenen. Meer bepaald ging het over de vacature van (1) tandtechnicus, (2) huis-aan-huis-verkoper, (3) verpakker, (4) installateur van plaatbewerkingsmachines, (5) laborant (cytogenetische technieken), (6) verzekeringsagent, (7) kinesitherapeut en (8) databankbeheerder. De verschillende jobs werden geselecteerd en gecategoriseerd op basis van data aangeleverd door O*Net (d.w.z. The Occupational Information Network). ${ }^{2}$ In de vacatures werd steeds de inhoud van de job kort beschreven. Deze jobbeschrijvingen werden uniform opgesteld volgens de beschrijvingen zoals deze te vinden zijn op O*Net. Elke participant kreeg lukraak (random) één van deze acht vacatures toegewezen op zo'n manier dat elke vacature ongeveer even vaak werd voorgelegd aan de participanten. ${ }^{3}$ We kozen ervoor om te werken met acht verschillende vacatures om zo de generaliseerbaarheid van onze resultaten te verhogen en te kunnen nagaan of de mate van leeftijdsdiscriminatie varieerde over deze verschillende typen van jobs.

Daarna werden de participanten ingelicht over het feit dat een administratief medewerker reeds vijf profielen had geselecteerd die formeel in aanmerking kwamen (inzake werkervaring en opleidingsniveau) voor de job. De kenmerken van de fictieve jobkandidaten - hierboven uiteengezet - werden samengevat in vijf tabellen (d.w.z. één tabel per jobkandidaat) en gepresenteerd aan de participanten op de volgende pagina's van het aan de participanten voorgelegde experimentele materiaal. Een voorbeeld van zo'n tabel kan worden gevonden in Tabel A.2 in de Bijlagen. De participanten dienden elk van de profielen te beoordelen aan de hand van in totaal 16 verschillende schalen (hierna de kandidaat-evaluatiescores genoemd). Dit waren 7-puntsschalen gaande van 1 (d.w.z. 'helemaal niet akkoord') tot 7 (d.w.z. 'helemaal akkoord'). Ten eerste dienden de participanten aan te geven in welke mate ze het eens waren met twee stellingen die betrekking hadden op twee selectiebeslissingen. Verder (dit onderdeel beschouwen wij als meer belangrijk) werden ook hun percepties en attituden jegens elke jobkandidaat gemeten.

Met betrekking tot de selectiebeslissingen dienden de participanten aan te geven met welke waarschijnlijkheid zij (1) een jobkandidaat zouden uitnodigen voor een jobinterview (hierna de interviewschaal genoemd) en (2) een jobkandidaat daadwerkelijk zouden aanstellen (hierna de aanstellingsschaal genoemd). De stellingen werden als volgt geformuleerd: 'Ik zal de kandidaat uitnodigen voor een sollicitatiegesprek bij Franssen NV voor de omschreven functie' en 'Er is een grote kans dat ik de kandidaat ook effectief zal aanstellen voor de functie bij Franssen NV'. $\mathrm{Na}$ het scoren van de interview- en aanstellingsschaal beoordeelden de participanten 14 stellingen die verband houden met de theorieën van statistische discrimina- 
tie (Arrow, 1973) en voorkeursdiscriminatie (Becker, 1957). De eerste 11 stellingen peilden naar de percepties van de participanten omtrent de productiviteit van de verschillende jobkandidaten (hierna de perceptieschalen genoemd). Concreet werden de jobkandidaten beoordeeld inzake hun veronderstelde (1) mentale capaciteiten, (2) sociale capaciteiten, (3) fysieke capaciteiten, (4) technologische knowhow, (5) flexibiliteit, (6) creativiteit, (7) ervaring in het beroep, (8) motivatie, (9) betrouwbaarheid, (10) nauwkeurigheid en (11) trainbaarheid. De percepties die gepeild werden, waren alle geassocieerd met stereotypen over de productiviteit van oudere werknemers en waren gekozen op basis van de literatuurstudie van Burn, Button, Corella en Neumark (2019). Voorbeelden van de gepresenteerde stellingen zijn: 'Ik denk dat deze persoon over voldoende intellectuele capaciteiten beschikt om naar behoren te presteren in deze job' en 'Ik denk dat deze persoon voldoende gemotiveerd zal zijn om naar behoren te presteren in deze job'. Zie Tabel A.3 in de Bijlagen. De laatste drie stellingen peilden naar de attituden van de participanten omtrent hun bereidheid om samen te werken met de jobkandidaten en naar hun perceptie betreffende de bereidheid van andere werknemers en klanten om samen te werken met de jobkandidaten (hierna de attitudeschalen genoemd). De stellingen zijn overgenomen van Baert en De Pauw (2014) en Van Borm en Baert (2018) en werden als volgt geformuleerd: 'Ik denk graag te zullen samenwerken met deze persoon', 'Ik denk dat andere werknemers graag zullen samenwerken met deze persoon' en 'Ik denk dat klanten graag zullen samenwerken met deze persoon'. Een overzicht van de 16 verschillende schalen met bijhorende stellingen is te vinden in de Bijlagen (Tabel A.3).

$\mathrm{Na}$ het beoordelen van de jobkandidaten lieten we de participanten een postexperimentele vragenlijst invullen met vragen over vier demografische kenmerken (d.w.z. hun leeftijd, geslacht (d.w.z. man of vrouw), opleidingsniveau (d.w.z. universitair onderwijs, hoger onderwijs buiten de universiteit, secundair onderwijs of lager dan secundair onderwijs) en nationaliteit (d.w.z. Belg, niet-Belg maar EU-28 of niet EU-28)) en vier job-gerelateerde kenmerken (d.w.z. de frequentie waarmee zij jobkandidaten evalueren (d.w.z. dagelijks, wekelijks, tweewekelijks, maandelijks, eens per semester, eens per jaar of minder frequent), hoelang zij reeds jobkandidaten evalueren (d.w.z. sinds dit jaar, reeds 1-5 jaar of reeds meer dan vijf jaar), het type job dat zij uitoefenen (d.w.z. manager, specialist inzake personeels- en loopbaanontwikkeling, uitzendbureaumedewerker, directie-assistent, algemeen administratief medewerker of andere) en het percentage oudere werknemers tewerkgesteld in hun bedrijf (d.w.z. o\%, 1-9\%, 10-19\%, 20-29\%, 30-39\% of $40 \%$ of meer). Deze acht vragen werden gesteld om te kunnen nagaan of de mate van leeftijdsdiscriminatie varieerde over deze kenmerken.

\subsection{Dataverzameling en -beschrijving}

De online survey werd aan de participanten aangeboden via e-mail. De participanten in ons experiment betroffen personen die genoemd werden als contactpersoon (recruiter) in vacatures uit de database van de Vlaamse Dienst voor Arbeidsbemiddeling en Beroepsopleiding (VDAB). Om de contactgegevens van deze recruiters te bekomen screenden we alle vacatures die tussen 3 en 13 april 2017 online stonden met een plaatsingsdatum in de week voorafgaand aan deze 
periode. In totaal screenden we 32.787 vacatures op e-mailadressen. In totaal verzamelden we zodoende 2697 unieke e-mailadressen waarnaar een link werd gestuurd die verwees naar het online experiment. Uiteindelijk vulden 193 van de 2697 benaderde individuen de survey volledig in, wat resulteerde in een responsgraad van $7.1 \%$. Aangezien elke participant vijf verschillende profielen beoordeelde, kwamen we uit op een totale sample van 965 sets van observaties (d.w.z. 193×5). In Tabel 1 geven we een beschrijving van de verzamelde data.

Uit Tabel 1, Kolom 1 blijkt dat het merendeel van onze steekproef vrouw was (d.w.z. 76.7\%), dat ongeveer de helft (d.w.z. 47.7\%) jonger was dan 35, dat zo goed als alle participanten de Belgische nationaliteit hadden (d.w.z. 98.4\%) en dat een kleine $38.0 \%$ van de participanten een universitair diploma had. Daarnaast blijkt ook dat de participanten in onze sample veel ervaring hadden op het gebied van werving en selectie. Concreet gaf 95.3\% van de participanten aan minstens één keer per semester jobkandidaten te evalueren en gaf ongeveer de helft (d.w.z. 48.7\%) van de participanten aan al meer dan vijf jaar ervaring te hebben in het evalueren van jobkandidaten. Tot slot gaf $40.9 \%$ van de participanten aan tewerkgesteld te zijn in een bedrijf waar minstens $20 \%$ van de werknemers uit oudere werknemers bestond.

Uit Tabel 1, Kolom (2), (3) en (4) kunnen we daarenboven concluderen dat het randomiseren van de leeftijd van de jobkandidaten over de verschillende participanten in het experiment (Paneel A) succesvol was. Meer concreet werden kandidaten jonger dan of even oud als 47.07 jaar geëvalueerd door participanten die zeer gelijkaardig waren (d.w.z. in termen van geslacht, leeftijd, nationaliteit, opleidingsniveau, ervaring in werving en selectie en het percentage oudere werknemers tewerkgesteld in hun bedrijf) aan de participanten die kandidaten evalueerden die ouder waren dan 47.07 jaar. Hetzelfde kan worden gezegd over de randomisering van de leeftijd van de jobkandidaten over de verschillende vacatures (Tabel 1, Kolom (2), (3) en (4), Paneel B). Ongeveer een zelfde aantal oudere en jongere jobkandidaten werd geëvalueerd voor elk van de acht vacatures.

\section{Resultaten}

In deze paragraaf bespreken we eerst wat het effect is van iemands leeftijd op diens tewerkstellingskansen (zie 3.1). In 3.2 beantwoorden we vervolgens onze eerste onderzoeksvraag, namelijk wat de mogelijke drijfveren zijn van leeftijdsdiscriminatie in het selectieproces. In 3.3 gaan we vervolgens dieper in op onze tweede onderzoeksvraag, namelijk de rol van moderatoren. Concreet bestuderen we of de mate van discriminatie varieert over verschillende participant- en job-kenmerken.

\subsection{Het effect van leeftijd op tewerkstellingskansen}

Om het effect van de leeftijd van de jobkandidaten op hun tewerkstellingskansen te exploreren, plotten we eerst de gemiddelde kans om uitgenodigd te worden voor een jobinterview (d.w.z. de gemiddelde scores op de interviewschaal) (Figuur $1 \mathrm{~A}$ ) en de gemiddelde kans om effectief aangesteld te worden (d.w.z. de gemiddelde scores op de aanstellingsschaal) (Figuur $1 \mathrm{~B}$ ) voor acht verschillende leeftijdscategorieën van de fictieve jobkandidaten in het experiment. 
Tabel 1 Databeschrijving

\begin{tabular}{|c|c|c|c|c|}
\hline & (I) & (2) & (3) & (4) \\
\hline Demografische kenmerken & $\begin{array}{l}\text { Totale } \\
\text { steekproef } \\
N=965\end{array}$ & $\begin{array}{l}\text { Kandidaten } \\
\text { met leeftijd } \\
\leq 47.07 \\
n=499\end{array}$ & $\begin{array}{l}\text { Kandidaten } \\
\text { met leeftijd } \\
>47.07 \\
n=466\end{array}$ & $\begin{array}{l}\text { Verschil } \\
\text { (3) - (2) }\end{array}$ \\
\hline & $\begin{array}{l}M \\
(S D)\end{array}$ & $\begin{array}{l}M \\
(S D)\end{array}$ & $\begin{array}{l}M \\
(S D)\end{array}$ & $\begin{array}{l}\text { M3-M2 } \\
{[T]}\end{array}$ \\
\hline \multicolumn{5}{|l|}{ A. Participant-kenmerken } \\
\hline Geslacht: vrouw & $\begin{array}{l}0.767 \\
(0.423)\end{array}$ & $\begin{array}{c}0.763 \\
(0.425)\end{array}$ & $\begin{array}{c}0.770 \\
(0.421)\end{array}$ & $\begin{array}{c}0.007 \\
{[0.252]}\end{array}$ \\
\hline Leeftijd: < 35 jaar & $\begin{array}{c}0.477 \\
(0.500)\end{array}$ & $\begin{array}{c}0.457 \\
(0.498)\end{array}$ & $\begin{array}{c}0.498 \\
(0.500)\end{array}$ & $\begin{array}{c}0.041 \\
{[1.272]}\end{array}$ \\
\hline Nationaliteit: Belgisch & $\begin{array}{l}0.984 \\
(0.124)\end{array}$ & $\begin{array}{l}0.986 \\
(0.118)\end{array}$ & $\begin{array}{c}0.983 \\
(0.130)\end{array}$ & $\begin{array}{l}-0.003 \\
{[-0.394]}\end{array}$ \\
\hline $\begin{array}{l}\text { Hoogst behaalde diploma: uni- } \\
\text { versitair }\end{array}$ & $\begin{array}{c}0.378 \\
(0.485)\end{array}$ & $\begin{array}{c}0.381 \\
(0.486)\end{array}$ & $\begin{array}{c}0.375 \\
(0.485)\end{array}$ & $\begin{array}{l}-0.005 \\
{[-0.167]}\end{array}$ \\
\hline $\begin{array}{l}\text { Frequentie van selectiebeslissin- } \\
\text { gen: } \geq \text { Ix per semester }\end{array}$ & $\begin{array}{l}0.953 \\
(0.211)\end{array}$ & $\begin{array}{c}0.948 \\
(0.222)\end{array}$ & $\begin{array}{c}0.959 \\
(0.198)\end{array}$ & $\begin{array}{c}0.011 \\
{[0.834]}\end{array}$ \\
\hline $\begin{array}{l}\text { Ervaring in werving en selectie: } \\
>5 \text { jaar }\end{array}$ & $\begin{array}{l}0.487 \\
(0.500)\end{array}$ & $\begin{array}{c}0.482 \\
(0.500)\end{array}$ & $\begin{array}{c}0.491 \\
(0.500)\end{array}$ & $\begin{array}{c}0.008 \\
{[0.262]}\end{array}$ \\
\hline $\begin{array}{l}\text { Percentage oudere werknemers } \\
\text { in bedrijf: } \geq 20 \%\end{array}$ & $\begin{array}{c}0.409 \\
(0.492)\end{array}$ & $\begin{array}{c}0.393 \\
(0.489)\end{array}$ & $\begin{array}{c}0.427 \\
(0.495)\end{array}$ & $\begin{array}{c}0.034 \\
{[1.08 \mid]}\end{array}$ \\
\hline \multicolumn{5}{|l|}{ B. Job-kenmerken } \\
\hline Tandtechnicus & $\begin{array}{l}0.135 \\
(0.342)\end{array}$ & $\begin{array}{l}0.126 \\
(0.332)\end{array}$ & $\begin{array}{c}0.144 \\
(0.351)\end{array}$ & $\begin{array}{c}0.017 \\
{[0.796]}\end{array}$ \\
\hline Huis-aan-huis-verkoper & $\begin{array}{l}0.114 \\
(0.318)\end{array}$ & $\begin{array}{l}0.108 \\
(0.311)\end{array}$ & $\begin{array}{c}0.120 \\
(0.325)\end{array}$ & $\begin{array}{c}0.012 \\
{[0.583]}\end{array}$ \\
\hline Verpakker & $\begin{array}{c}0.140 \\
(0.347)\end{array}$ & $\begin{array}{c}0.142 \\
(0.350)\end{array}$ & $\begin{array}{c}0.137 \\
(0.345)\end{array}$ & $\begin{array}{l}-0.005 \\
{[-0.22 I]}\end{array}$ \\
\hline $\begin{array}{l}\text { Installateur van plaatbewerkings- } \\
\text { machines }\end{array}$ & $\begin{array}{l}0.109 \\
(0.3 \mid 2)\end{array}$ & $\begin{array}{c}0.118 \\
(0.323)\end{array}$ & $\begin{array}{c}0.099 \\
(0.299)\end{array}$ & $\begin{array}{l}-0.019 \\
{[-0.973]}\end{array}$ \\
\hline $\begin{array}{l}\text { Laborant (cytogenetische tech- } \\
\text { nieken) }\end{array}$ & $\begin{array}{l}0.124 \\
(0.330)\end{array}$ & $\begin{array}{c}0.124 \\
(0.330)\end{array}$ & $\begin{array}{c}0.124 \\
(0.330)\end{array}$ & $\begin{array}{c}0.000 \\
{[0.010]}\end{array}$ \\
\hline Verzekeringsagent & $\begin{array}{l}0.109 \\
(0.312)\end{array}$ & $\begin{array}{c}0.102 \\
(0.303)\end{array}$ & $\begin{array}{c}0.116 \\
(0.320)\end{array}$ & $\begin{array}{c}0.014 \\
{[0.68 \mid]}\end{array}$ \\
\hline Kinesitherapeut & $\begin{array}{l}0.155 \\
(0.362)\end{array}$ & $\begin{array}{l}0.166 \\
(0.373)\end{array}$ & $\begin{array}{c}0.144 \\
(0.351)\end{array}$ & $\begin{array}{l}-0.022 \\
{[-0.966]}\end{array}$ \\
\hline Databankbeheerder & $\begin{array}{l}0.114 \\
(0.3 \mid 8)\end{array}$ & $\begin{array}{c}0.112 \\
(0.3 \mid 6)\end{array}$ & $\begin{array}{c}0.116 \\
(0.320)\end{array}$ & $\begin{array}{c}0.004 \\
{[0.178]}\end{array}$ \\
\hline
\end{tabular}

NB. 47.07 jaar werd als afkappingswaarde genomen, daar deze waarde het steekproefgemiddelde van de leeftijd van de kandidaten betreft. $* p<.10$, ** $p<.05$, *** $p<.0$ I. 


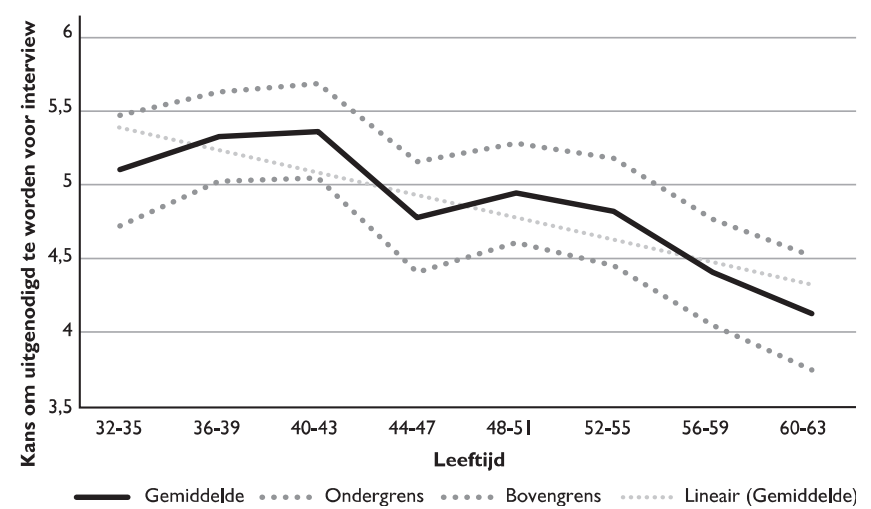

Figuur 1A Kans om uitgenodigd te worden voor een jobinterview per leeftijdscategorie NB. De grijze stippellijnen staan respectievelijk voor de onder-en bovengrens van het $95 \%$-betrouwbaarheidsinterval. De rechte stippellijn geeft de trendlijn van de gemiddelde scores weer.

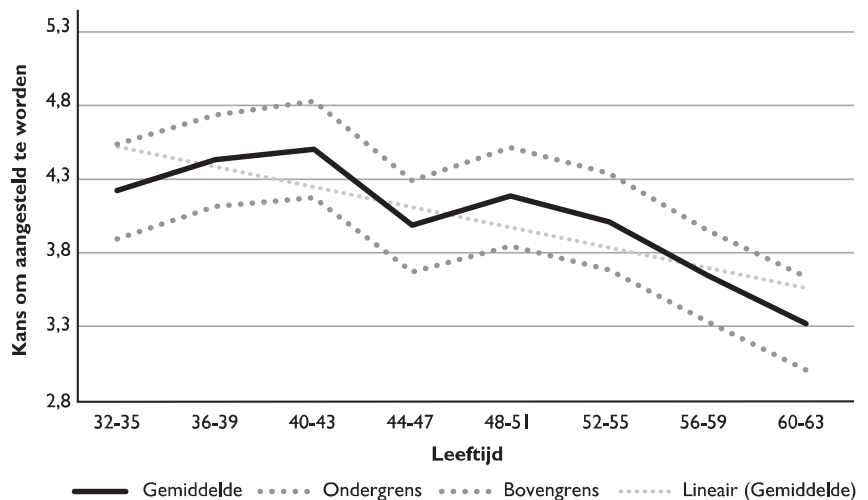

Figuur 1B Kans om aangesteld te worden per leeftijdscategorie NB. De grijze stippellijnen staan respectievelijk voor de onder- en bovengrens van het $95 \%$-betrouwbaarheidsinterval. De rechte stippellijn geeft de trendlijn van de gemiddelde scores weer.

Beide figuren suggereren dat leeftijd inderdaad een negatieve invloed heeft op iemands tewerkstellingskansen. In beide figuren is namelijk duidelijk te zien dat iemands kansen om uitgenodigd te worden voor een jobinterview of om effectief aangesteld te worden, geringer zijn naarmate men ouder is.

Vervolgens gingen we na of de gemiddelde kans om uitgenodigd te worden voor een interview en effectief aangesteld te worden verschilden tussen jongere en oudere jobkandidaten. Hiervoor deelden we onze steekproef op in twee deelsteekproeven: jobkandidaten jonger dan of even oud als 47.07 jaar (d.w.z. het steek- 
proefgemiddelde van de leeftijd van de kandidaten) en jobkandidaten ouder dan 47.07 jaar. We maakten gebruik van verschillende $T$-testen om na te gaan of de gemiddelde aanstellingskansen significant verschilden tussen de twee deelsteekproeven. De resultaten van deze analyse kunnen worden gevonden in Tabel 2 (Paneel A).

Tabel 2 Relatie tussen de leeftijd van de fictieve jobkandidaten en de kandidaat-evaluatiescores

\begin{tabular}{|c|c|c|c|c|}
\hline & (I) & (2) & (3) & (4) \\
\hline Kandidaat-evaluatiescores & $\begin{array}{l}\text { Totale } \\
\text { steekproef } \\
N=965\end{array}$ & $\begin{array}{l}\text { Kandidaten } \\
\text { met leeftijd } \\
\leq 47.07 \\
n=499\end{array}$ & $\begin{array}{l}\text { Kandidaten } \\
\text { met leeftijd } \\
>47.07 \\
n=466\end{array}$ & $\begin{array}{l}\text { Verschil } \\
(3)-(2)\end{array}$ \\
\hline & $\begin{array}{l}M \\
(S D)\end{array}$ & $\begin{array}{l}M \\
(S D)\end{array}$ & $\begin{array}{l}M \\
(S D)\end{array}$ & $\begin{array}{l}\text { M3-M2 } \\
{[T]}\end{array}$ \\
\hline \multicolumn{5}{|l|}{$\begin{array}{l}\text { A. Interview- en aanstel- } \\
\text { lingsschaal }\end{array}$} \\
\hline $\begin{array}{l}\text { Kans om uitgenodigd te worden } \\
\text { voor jobinterview }\end{array}$ & $\begin{array}{l}4.370 \\
(1.919)\end{array}$ & $\begin{array}{l}5.148 \\
(1.889)\end{array}$ & $\begin{array}{c}4.573 \\
(1.907)\end{array}$ & $\begin{array}{l}-0.575 \text { *** } \\
{[-4.705]}\end{array}$ \\
\hline Kans om aangesteld te worden & $\begin{array}{c}4.055 \\
(1.642)\end{array}$ & $\begin{array}{c}4.287 \\
(1.653)\end{array}$ & $\begin{array}{l}3.807 \\
(1.595)\end{array}$ & $\begin{array}{l}-0.480 * * * \\
{[-4.583]}\end{array}$ \\
\hline \multicolumn{5}{|l|}{ B. Perceptieschalen } \\
\hline $\begin{array}{l}\text { Veronderstelde mentale } \\
\text { capaciteiten }\end{array}$ & $\begin{array}{l}4.706 \\
(1.176)\end{array}$ & $\begin{array}{l}4.719 \\
(1.120)\end{array}$ & $\begin{array}{c}4.691 \\
(1.233)\end{array}$ & $\begin{array}{c}-0.028 \\
{[-0.375]}\end{array}$ \\
\hline $\begin{array}{l}\text { Veronderstelde sociale } \\
\text { capaciteiten }\end{array}$ & $\begin{array}{l}4.660 \\
(1.052)\end{array}$ & $\begin{array}{l}4.643 \\
(1.020)\end{array}$ & $\begin{array}{c}4.678 \\
(1.085)\end{array}$ & $\begin{array}{c}0.035 \\
{[0.5 \mid 4]}\end{array}$ \\
\hline $\begin{array}{l}\text { Veronderstelde fysieke } \\
\text { capaciteiten }\end{array}$ & $\begin{array}{c}4.586 \\
(1.122)\end{array}$ & $\begin{array}{c}4.731 \\
(1.110)\end{array}$ & $\begin{array}{l}4.431 \\
(1.115)\end{array}$ & $\begin{array}{l}-0.300 \text { *⿻丷木标 } \\
{[-4.187]}\end{array}$ \\
\hline $\begin{array}{l}\text { Veronderstelde technologische } \\
\text { kennis en skills }\end{array}$ & $\begin{array}{c}4.472 \\
(1.248)\end{array}$ & $\begin{array}{l}4.525 \\
(1.196)\end{array}$ & $\begin{array}{l}4.416 \\
(1.30 I)\end{array}$ & $\begin{array}{l}-0.109 \\
{[-1.353]}\end{array}$ \\
\hline Veronderstelde flexibiliteit & $\begin{array}{l}4.285 \\
(1.078)\end{array}$ & $\begin{array}{l}4.317 \\
(1.037)\end{array}$ & $\begin{array}{l}4.251 \\
(1.120)\end{array}$ & $\begin{array}{c}-0.066 \\
{[-0.944]}\end{array}$ \\
\hline Veronderstelde creativiteit & $\begin{array}{l}4.295 \\
(0.895)\end{array}$ & $\begin{array}{l}4.317 \\
(0.878)\end{array}$ & $\begin{array}{c}4.272 \\
(0.914)\end{array}$ & $\begin{array}{c}-0.044 \\
{[-0.764]}\end{array}$ \\
\hline Veronderstelde ervaring & $\begin{array}{c}4.57 \mid \\
(1.773)\end{array}$ & $\begin{array}{l}4.587 \\
(1.819)\end{array}$ & $\begin{array}{c}4.554 \\
(1.725)\end{array}$ & $\begin{array}{c}-0.033 \\
{[-0.293]}\end{array}$ \\
\hline Veronderstelde motivatie & $\begin{array}{c}4.489 \\
(1.008)\end{array}$ & $\begin{array}{l}4.505 \\
(0.987)\end{array}$ & $\begin{array}{c}4.472 \\
(1.031)\end{array}$ & $\begin{array}{c}-0.033 \\
{[-0.507]}\end{array}$ \\
\hline $\begin{array}{l}\text { Veronderstelde betrouwbaar- } \\
\text { heid }\end{array}$ & $\begin{array}{l}4.4 \mid 4 \\
(0.972)\end{array}$ & $\begin{array}{l}4.335 \\
(0.928)\end{array}$ & $\begin{array}{l}4.500 \\
(1.010)\end{array}$ & $\begin{array}{l}0.165^{* * * *} \\
{[2.649]}\end{array}$ \\
\hline Veronderstelde nauwkeurigheid & $\begin{array}{l}4.407 \\
(0.975)\end{array}$ & $\begin{array}{l}4.361 \\
(0.926)\end{array}$ & $\begin{array}{l}4.457 \\
(1.024)\end{array}$ & $\begin{array}{r}0.096 \\
{[1.535]}\end{array}$ \\
\hline Veronderstelde trainbaarheid & $\begin{array}{l}4.283 \\
(1.114)\end{array}$ & $\begin{array}{c}4.483 \\
(1.070)\end{array}$ & $\begin{array}{c}4.069 \\
(1.120)\end{array}$ & $\begin{array}{l}-0.4 \mid 4 * * * \\
{[-5.874]}\end{array}$ \\
\hline
\end{tabular}




\begin{tabular}{lcccc}
\hline C.Attitudeschalen & & & & \\
Bereidheid van participant om & 4.304 & 4.355 & 4.249 & $-0.106 *$ \\
samen te werken & $(0.902)$ & $(0.848)$ & $(0.954)$ & {$[-1.823]$} \\
Bereidheid van werknemers om & 4.268 & 4.333 & 4.200 & $-0.133^{* *}$ \\
samen te werken & $(0.890)$ & $(0.859)$ & $(0.921)$ & {$[-2.327]$} \\
Bereidheid van klanten om & 4.309 & 4.305 & 4.313 & 0.009 \\
samen te werken & $(0.962)$ & $(0.927)$ & $(0.999)$ & {$[0.140]$} \\
\hline
\end{tabular}

NB. $* p<.10, * * p<.05, * * * p<.01$.

Uit Paneel A van Tabel 2 blijkt dat jobkandidaten ouder dan 47.07 jaar inderdaad significant lagere scores kregen op zowel de interviewschaal (d.w.z. $M=4.573$ vs. $M=5.148, p<.01)$ als de aanstellingsschaal $(M=3.807$ vs. $M=4.287, p<.01)$ dan jobkandidaten die jonger dan of even oud waren als 47.07 jaar.

In een alternatieve analyse berekenden we daarenboven de correlatiecoëfficiënten tussen de leeftijd van de jobkandidaten en de interview- en aanstellingsschaal (zie Tabel 3, Paneel A, Kolom 1) en voerden we twee regressieanalyses uit, waarbij de gestandaardiseerde versies van de interviewschaal en aanstellingsschaal fungeerden als afhankelijke variabelen en de leeftijd van de fictieve jobkandidaten als onafhankelijke variabele (zie Tabel 3, Paneel A, Kolom 2).

Tabel 3 Relatie tussen de leeftijd van de fictieve jobkandidaten en de kandidaat-evaluatiescores (alternatieve analyses) $(N=965)$

\begin{tabular}{lll}
\hline & $(\mathbf{I})$ & $\mathbf{( 2 )}$ \\
\hline Kandidaat-evaluatiescores & $\begin{array}{l}\text { Pearson correla- } \\
\text { tiecoëfficiënten }\end{array}$ & $\begin{array}{l}\text { Regressiecoëffi- } \\
\text { ciënten }\end{array}$ \\
\hline A. Interview- en aanstellingsschaal & & \\
Kans om uitgenodigd te worden voor jobinterview & $-\mathbf{0 . 1 8 4}$ & $-\mathbf{0 . 0 2 0}$ \\
& {$[0.000]$} & {$[0.000]$} \\
Kans om aangesteld te worden & $-\mathbf{0 . 1 8 2}$ & $-\mathbf{0 . 0 2 0}$ \\
& {$[0.000]$} & {$[0.000]$} \\
\hline B. Perceptieschalen & & \\
Veronderstelde mentale capaciteiten & -0.026 & -0.003 \\
& {$[0.415]$} & {$[0.400]$} \\
Veronderstelde sociale capaciteiten & -0.008 & -0.001 \\
& {$[0.795]$} & {$[0.784]$} \\
Veronderstelde fysieke capaciteiten & -0.173 & -0.019 \\
Veronderstelde technologische kennis en skills & {$[0.000]$} & {$[0.000]$} \\
& -0.079 & -0.008 \\
Veronderstelde flexibiliteit & {$[0.014]$} & {$[0.025]$} \\
& -0.067 & -0.007 \\
Veronderstelde creativiteit & {$[0.036]$} & {$[0.046]$} \\
& -0.051 & -0.005 \\
& {$[0.114]$} & {$[0.105]$}
\end{tabular}




\begin{tabular}{|c|c|c|}
\hline & ( & (2) \\
\hline Kandidaat-evaluatiescores & $\begin{array}{l}\text { Pearson correla- } \\
\text { tiecoëfficiënten }\end{array}$ & $\begin{array}{l}\text { Regressiecoëffi- } \\
\text { ciënten }\end{array}$ \\
\hline Veronderstelde ervaring & $\begin{array}{l}-0.028 \\
{[0.391]}\end{array}$ & $\begin{array}{l}-0.003 \\
{[0.417]}\end{array}$ \\
\hline Veronderstelde motivatie & $\begin{array}{l}-0.032 \\
{[0.323]}\end{array}$ & $\begin{array}{l}-0.003 \\
{[0.290]}\end{array}$ \\
\hline Veronderstelde betrouwbaarheid & $\begin{array}{l}0.067 \\
{[0.037]}\end{array}$ & $\begin{array}{r}0.007 \\
{[0.035]}\end{array}$ \\
\hline Veronderstelde nauwkeurigheid & $\begin{array}{c}0.037 \\
{[0.256]}\end{array}$ & $\begin{array}{c}0.004 \\
{[0.250]}\end{array}$ \\
\hline Veronderstelde trainbaarheid & $\begin{array}{l}-0.253 \\
{[0.000]}\end{array}$ & $\begin{array}{l}-0.027 \\
{[0.000]}\end{array}$ \\
\hline \multicolumn{3}{|l|}{ C.Attitudeschalen } \\
\hline Bereidheid van participant om samen te werken & $\begin{array}{l}-0.096 \\
{[0.003]}\end{array}$ & $\begin{array}{l}-0.010 \\
{[0.006]}\end{array}$ \\
\hline Bereidheid van werknemers om samen te werken & $\begin{array}{l}-0.109 \\
{[0.001]}\end{array}$ & $\begin{array}{l}-0.012 \\
{[0.002]}\end{array}$ \\
\hline Bereidheid van klanten om samen te werken & $\begin{array}{l}-0.024 \\
{[0.448]}\end{array}$ & $\begin{array}{l}-0.003 \\
{[0.483]}\end{array}$ \\
\hline
\end{tabular}

NB. Spearman correlatiecoëfficiënten werden ook berekend voor Kolom I en leidden tot exact dezelfde conclusies. $p$-waarden worden gepresenteerd tussen vierkante haakjes en zijn gecorrigeerd voor clustering van de observaties op het participanten-niveau. Regressie- en correlatiecoëfficiënten met een $p$-waarde kleiner dan .05 zijn vetgedrukt.

Ook dit leverde gelijkaardige resultaten op. Zo vinden we een sterk significante negatieve correlatie tussen de leeftijd van jobkandidaten en de interview- en aanstellingsschaal (resp. -0.184, $p<.01$ en $-0.182, p<.01$ ) (zie Tabel 3, Paneel 1 , Kolom 1 ) en vinden we dat een stijging van één jaar in leeftijd leidt tot een $2.0 \%$ van een standaardafwijking (d.w.z. -0.20) lagere score op zowel de interview-als aanstellingsschaal $(p<.01)$ (zie Tabel 3, Paneel A, Kolom 2).

Op basis van de gepresenteerde analyses kunnen we derhalve stellen dat ook wij suggestief bewijs vinden voor het optreden van discriminatie in het selectieproces op basis van de leeftijd van de kandidaten. We dienen deze resultaten echter met een zekere voorzichtigheid te interpreteren. Onze onderzoeksmethode is namelijk niet de meest geschikte om discriminatie in het selectieproces te meten - veldexperimenten, zoals van Baert, Norga, Thuy en Van Hecke (2016) zijn hiervoor het meest geschikt - maar wel om de achterliggende mechanismen van dit type discriminatie te identificeren. Dit laatste is wat we bestuderen in de volgende sub-sectie (zie 3.2).

\subsection{De drijfueren van leeftijdsdiscriminatie in het selectieproces}

Om na te gaan wat de achterliggende mechanismen zijn van aanstellingsdiscriminatie ten aanzien van oudere jobkandidaten, voerden we twee verschillende soorten analyses uit: (1) een bivariate analyse en (2) een meervoudige mediatie-analyse. We bespreken beide analyses opeenvolgend in de volgende paragrafen. 


\section{- Bivariate analyse}

Om te exploreren wat de mogelijke drijfveren zijn van leeftijdsdiscriminatie in het selectieproces, gingen we in deze bivariate analyse te werk in twee afzonderlijke stappen. In een eerste stap bestudeerden we de relatie tussen de leeftijd van de fictieve jobkandidaten en de verschillende perceptie- en attitudeschalen. Om dit na te gaan vergeleken we in lijn met hierboven eerst de gemiddelde scores op de verschillende perceptie- en attitudeschalen van jongere (d.w.z. jobkandidaten jonger dan en even oud als het steekproefgemiddelde van 47.07 jaar) en oudere jobkandidaten (d.w.z. jobkandidaten ouder dan het steekproefgemiddelde van 47.07 jaar) aan de hand van $T$-testen. De resultaten van deze analyses zijn te vinden in Tabel 2, Paneel B en $C$.

Uit deze analyses blijkt dat oudere jobkandidaten lagere scores kregen op de stellingen gerelateerd aan hun veronderstelde fysieke capaciteiten ( $M=4.431 \mathrm{vs.} M=$ 4.731, $p<.01)$ en trainbaarheid $(M=4.069$ vs. $M=4.483, p<.01)$ en een hogere score kregen op de stelling gerelateerd aan hun veronderstelde betrouwbaarheid ( $M=4.500$ vs. $M=4.335, p<.01)$, in vergelijking met jongere jobkandidaten. Deze verschillen in scores zijn alle sterk significant verschillend van nul (d.w.z. op het 1\%-niveau). Daarnaast vinden we ook significante verschillen tussen oudere en jongere jobkandidaten betreffende de scores omtrent de bereidheid van werknemers, alsook van recruiters zelf, om samen te werken met de jobkandidaten. Concreet geloven recruiters dat hun werknemers minder graag zouden samenwerken met oudere jobkandidaten dan met jongere $(M=4.200$ vs. $M=4.333, p<.05)$ en geven zij ook aan zelf minder graag samen te werken met oudere jobkandidaten $(M=4.249$ vs. $M=4.355, p<.10)$. Deze verschillen zijn echter minder statistisch significant verschillend van nul (d.w.z. respectievelijk op het 5\%-en 10\%-niveau). In lijn met hierboven berekenden we vervolgens in een alternatieve analyse de correlatiecoëfficiënten tussen de leeftijd van de jobkandidaten en de verschillende perceptie- en attitudeschalen (zie Tabel 3, Paneel B en C, Kolom 1) en voerden we wederom verschillende regressieanalyses uit waarin de gestandaardiseerde versies van de verschillende perceptie- en attitudeschalen fungeerden als afhankelijke variabelen en de leeftijd van de jobkandidaten als onafhankelijke variabele (zie Tabel 3, Paneel B en C, Kolom 2).

Uit Tabel 3 valt af te lezen dat de samenhang tussen de leeftijd van de jobkandidaten en de perceptie- en attitudeschalen significant verschilt van nul voor zeven van de schalen. Inzake de perceptieschalen vinden we een significante negatieve relatie tussen de leeftijd van de jobkandidaten en (1) hun fysieke capaciteiten, (2) hun technologische knowhow, (3) hun flexibiliteit en (4) hun trainbaarheid. Dit blijkt uit zowel de correlatiecoëfficiënten als de regressiecoëfficiënten. Concreet vinden we een sterk significante negatieve correlatie tussen de leeftijd van de jobkandidaten en bovengenoemde perceptieschalen (respectievelijk -0.173, $p<.01$; -0.079, $p<.05 ;-0.067, p<.05$ en -0.253, $p<.01$ ) (zie Tabel 3, Paneel B, Kolom 1) en vinden we dat een extra jaar in leeftijd leidt tot respectievelijk een $1.9 \%, 0.8 \%, 0.7 \%$ en $2.7 \%$ van een standaardafwijking lagere score op de gerelateerde perceptieschalen (zie Tabel 3, Paneel B, Kolom 2). Grafische voorstellingen van deze resultaten waarin we de gemiddelde scores op de bovengenoemde perceptieschalen per leeftijdscategorie voorstellen in een grafiek, kunnen worden gevonden in Figuur $\mathrm{A}_{1}, \mathrm{~A}_{2}, \mathrm{~A}_{3}$ en $\mathrm{A}_{4}$ in 
de Bijlagen. Daarnaast vinden we ook een positieve relatie tussen de leeftijd van de jobkandidaten en hun veronderstelde betrouwbaarheid (d.w.z. we vinden een positieve correlatie tussen de leeftijd van de jobkandidaten en hun veronderstelde betrouwbaarheid (d.w.z. 0.067, $p<.05$ ) en we vinden dat een extra jaar in leeftijd leidt tot een $0.7 \%$ van een standaardafwijking hogere score op de desbetreffende perceptieschaal) (zie Tabel 3, Paneel B, Kolom 1 en 2). Deze resultaten liggen derhalve in grote mate in lijn met de resultaten gevonden in Tabel 2, met de uitzondering dat we nu ook (sterk) significante resultaten bekomen betreffende de veronderstelde technologische knowhow en flexibiliteit van jobkandidaten.

Inzake de attitudeschalen vinden we ook heel gelijkaardige resultaten als in Tabel 2. Concreet vinden we wederom een significante negatieve samenhang tussen de leeftijd van de jobkandidaten en (1) de bereidheid van de participanten om samen te werken met een jobkandidaat en (2) de perceptie van de participanten omtrent de bereidheid van andere werknemers om samen te werken met een jobkandidaat. Dit blijkt uit zowel de correlatiecoëfficiënten als de regressiecoëfficiënten (d.w.z. we vinden een negatieve correlatie tussen de leeftijd van de jobkandidaten en de verwachte bereidheid van recruiters en werknemers om samen te werken met de jobkandidaten (d.w.z. respectievelijk -0.096, $p<.01$ en $-0.109, p<.01$ ) en we vinden dat een jaar extra in leeftijd leidt tot respectievelijk een $1.0 \%$ en $1.2 \%$ van een standaardafwijking lagere score op de gerelateerde attitudeschalen) (zie Tabel 3, Paneel C, Kolom 1 en 2).

In een tweede stap bestudeerden we vervolgens de relatie tussen de verschillende perceptie- en attitudeschalen en de interview- en aanstellingsschaal. Daar we deze relatie geen causale interpretatie kunnen geven, omdat we de verschillende perceptie- en attitudeschalen niet experimenteel manipuleerden, berekenden we hier enkel de correlatiecoëfficiënten tussen de verschillende perceptie- en attitudeschalen en de interview- en aanstellingsschaal. De resultaten van deze analyse kunnen worden gevonden in Tabel 4.

Uit Kolom (1) en (2) van Tabel 4 blijkt duidelijk dat de verschillende perceptie- en attitudeschalen positief en sterk gecorreleerd zijn met zowel de interviewschaal als de aanstellingsschaal. Met andere woorden, hogere scores worden op de verschillende perceptie- en attitudeschalen geassocieerd met hogere aanstellingskansen.

Op basis van de resultaten die zijn gevonden in Tabel 2, 3 en 4, zouden we dus kunnen concluderen dat voornamelijk de negatieve percepties omtrent de jobkandidaten hun (1) fysieke capaciteiten, (2) technologische knowhow, (3) flexibiliteit en (4) trainbaarheid, alsook de lagere bereidheid van recruiters en werknemers om samen te werken met oudere jobkandidaten de leeftijdsdiscriminatie in het aanstellingsproces (gevonden in 3.1) verklaren. Uit Tabel 4 (Kolommen 3-16) valt echter te lezen dat de verschillende verklaringen sterk gecorreleerd zijn met elkaar. Het zou dus kunnen dat de associaties die we vonden in deze paragraaf, valse associaties zijn die echte relaties oppikken. Om hiermee rekening te houden voeren we een meervoudig mediatiemodel uit dat we bespreken in de volgende paragraaf. 


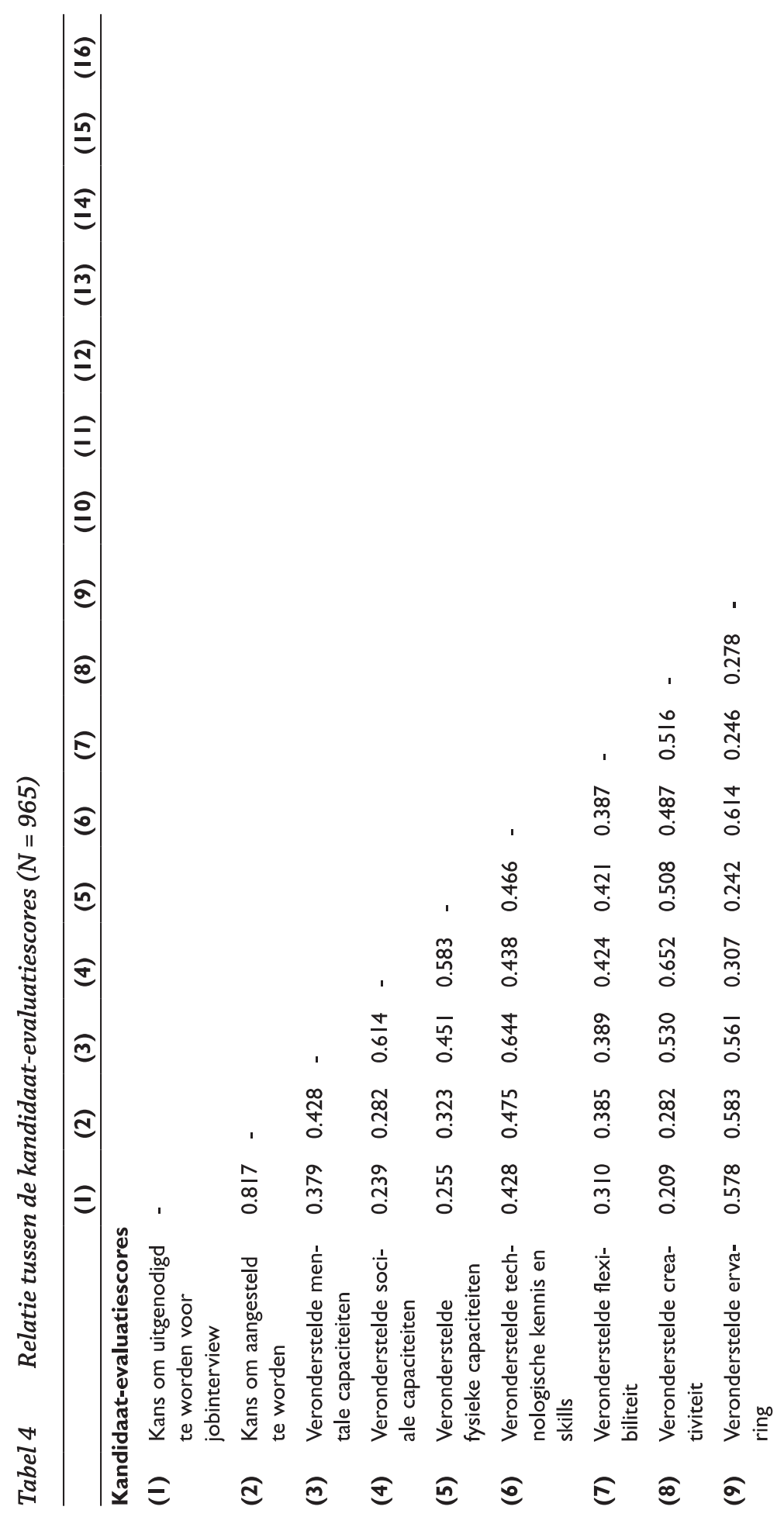




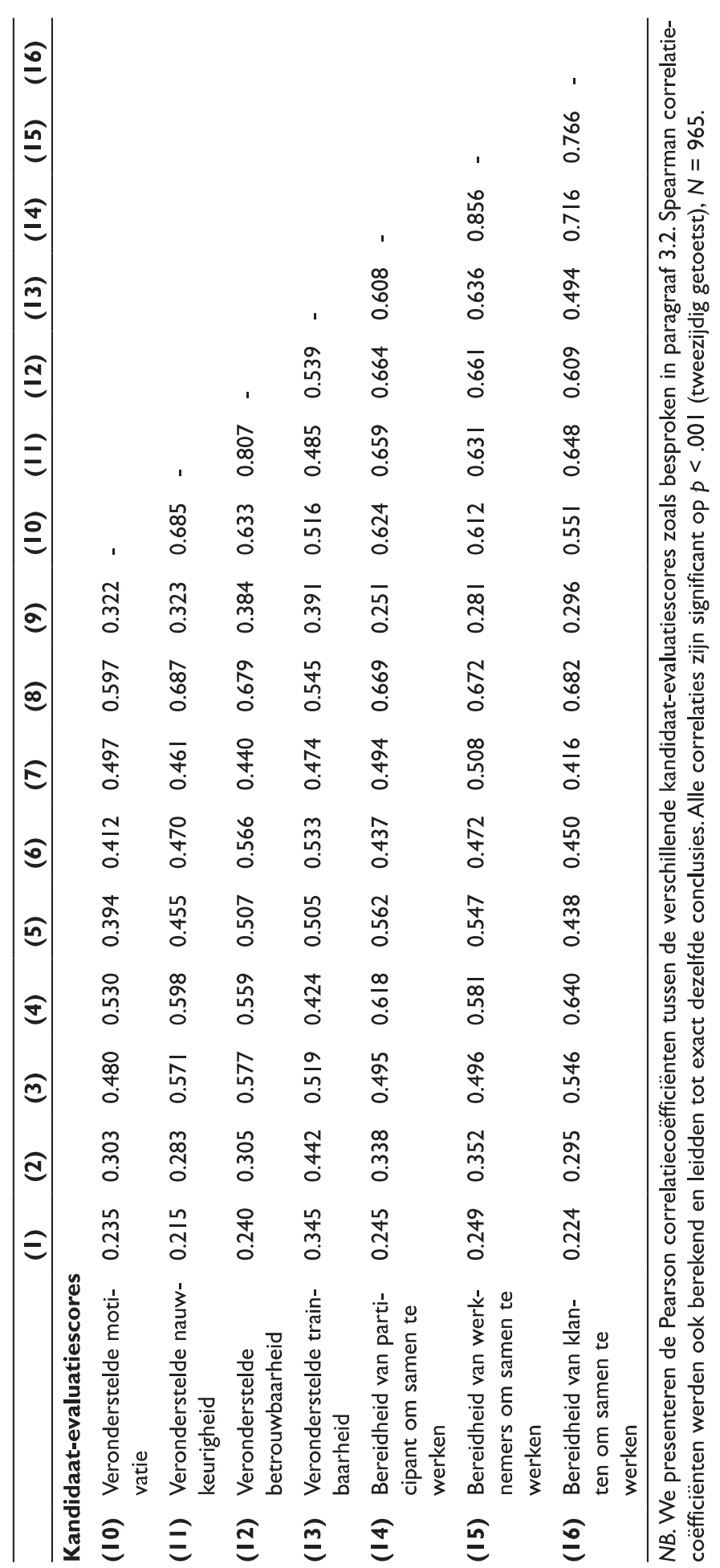




\section{- Meervoudig mediatiemodel}

In een meervoudig mediatiemodel ontleden we het totale leeftijdseffect in verschillende indirecte effecten via de verschillende perceptie- en attitudeschalen - ook mediatie-effecten genoemd - en een overblijvend 'direct' effect. Hierbij bestaan de verschillende mediatie-effecten uit twee deel-effecten (d.w.z. (1) het effect van de leeftijd van de jobkandidaten op de verschillende perceptie- en attitudeschalen en (2) het effect van de perceptie- en attitudeschalen op de interview- en aanstellingsschaal) die vermenigvuldigd worden. ${ }^{4} \mathrm{Om}$ de verschillende mediatie-effecten te berekenen voerden we een mediatie-analyse uit waarin alle perceptie- en attitudeschalen gezamenlijk opgenomen werden en een systeem van 15 regressieanalyses werd uitgevoerd volgens de richtlijnen genoemd in Hayes (2013). De controlevariabelen uit Van Borm et al. (2019) werden daarenboven opgenomen in elk van deze regressieanalyses. Voor een meer technische en gedetailleerde bespreking van het gerunde mediatie-model verwijzen wij graag naar Van Borm et al. (2019). De resultaten van deze meervoudige mediatie-analyse zijn te vinden in Figuur 2. We presenteren zowel de resultaten inzake (1) de interviewschaal als (2) de aanstellingsschaal.

Uit deze analyses blijkt dat in totaal 31.0\% van het leeftijdseffect op iemands kansen uitgenodigd te worden voor een jobinterview wordt verklaard door ons model. Hierbij zijn de impressies van recruiters dat oudere jobkandidaten over minder (1) technologische kennis en vaardigheden, (2) flexibiliteit en (3) relevante ervaring beschikken, de voornaamste verklaringen voor het totale (negatieve) leeftijdseffect. Concreet wordt respectievelijk 4.0\% ( $p<.10), 4.0 \%(p<.10)$ en $7.0 \%(p<.05)$ van het totale leeftijdseffect op de interviewschaal verklaard door deze drie perceptieschalen. Kijken we naar de resultaten betreffende de aanstellingsschaal, dan vinden we dat $46.0 \%$ van het totale leeftijdseffect verklaard wordt door ons model. De verschillende perceptie- en attitudeschalen die fungeren als voornaamste verklaringen voor dit totale effect, komen sterk overeen met de schalen die werden gevonden voor de interviewschaal (resp. 4.0\% ( $p<.10), 6.0 \%(p<.10)$ en 7.0\% $(p<.05)$, zij het dat ook de perceptie van de participanten omtrent de lagere trainbaarheid van oudere jobkandidaten een significante verklarende factor blijkt te zijn voor het negatieve effect van iemands leeftijd op diens tewerkstellingskansen. ${ }^{5}$ De perceptie omtrent de trainbaarheid van de jobkandidaten verklaart namelijk 12.0\% $(p<.05)$ van het totale leeftijdseffect op de aanstellingsschaal, terwijl deze mediator niet significant is inzake de interviewschaal. Een tabelmatige presentatie van deze resultaten kan worden gevonden in de Bijlagen (Tabel A.4).

\subsection{Moderatoren van leeftijdsdiscriminatie in het selectieproces}

Tot slot bestudeerden we verschillende mogelijke moderatoren van leeftijdsdiscriminatie in het selectieproces, door na te gaan of de mate van leeftijdsdiscriminatie varieerde over verscheidene participant- en job-kenmerken. Op basis van voorgaand onderzoek verwachtten we namelijk dat oudere jobkandidaten gunstiger zouden worden behandeld door oudere HR-professionals in vergelijking met jongere HR-professionals, daar zij zich mogelijk meer identificeren met deze jobkandidaten (d.w.z. in-group bias; Finkelstein, Burke, \& Raju, 1995; Jensen, De Tavernier, \& Nielsen, in press; Van Dalen, Henkens, \& Schippers, 2009). Daarnaast 


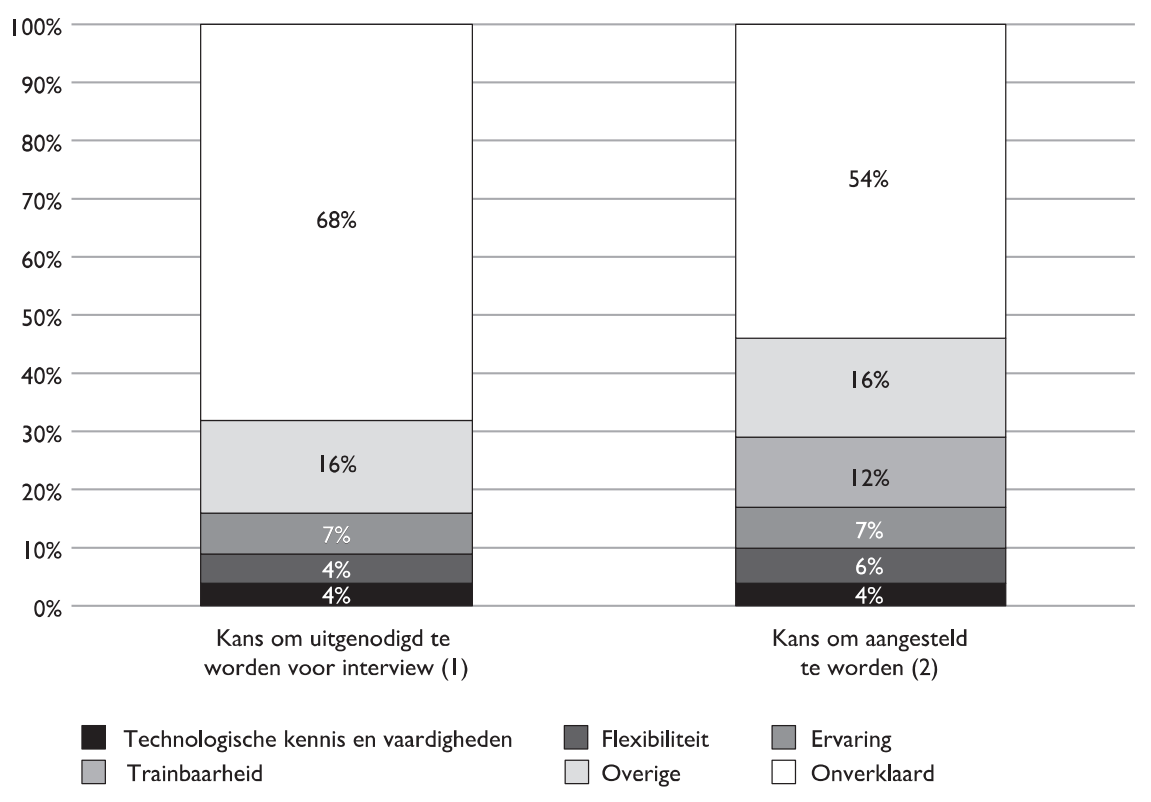

Figuur 2 Percentage totale leeftijdseffect op (1) kans om uitgenodigd te worden voor interview en (2) kans om aangesteld te worden, verklaard door perceptie- en attitudeschalen $N B$. De dominante verklaringen (d.w.z. mediatoren met $p$-waarden kleiner dan .10) voor de (lagere) kansen van oudere jobkandidaten om uitgenodigd te worden voor een interview en effectief aangesteld te worden, worden aangeduid met afzonderlijke kleurblokken. 'Overige' staat voor de niet-significante mediatoren (d.w.z. mediatoren met $p$-waarden groter dan .10). 'Onverklaard' staat voor het deel van het leeftijdseffect dat niet verklaard kon worden door de mediatoren die zijn opgenomen in het gepresenteerde mediatiemodel. $N=965$.

viel ook te verwachten dat personen die tewerkgesteld zijn in een bedrijf waar veel oudere werknemers werkzaam zijn, oudere jobkandidaten mogelijk meer positief zouden evalueren, omdat het contact dat zij hebben met oudere werknemers ertoe kan leiden dat zij meer positieve attituden hebben jegens hen, alsook in mindere mate geloven in de stereotypen die over hen bestaan (d.w.z. 'in-group contact hypothesis'; Allport, 1979; Jensen et al., in press). Tot slot verwachtten we een hogere mate van leeftijdsdiscriminatie te vinden in banen waarvoor (1) hoge algemene vaardigheden, (2) een hoog niveau van klantencontact, (3) grote fysieke inspanningen en (4) een grote mate van technologische knowhow vereist zijn (bijv. Finkelstein et al., 1995; Macan, Detjen, \& Dickey, 1994; Perry \& Finkelstein, 1999; Perry, Kulik, \& Bourhis, 1996; Posthuma \& Campion, 2009).

$\mathrm{Om}$ na te gaan of de bovengenoemde moderatie-effecten inderdaad gevonden werden, voerden we een multivariate regressie-analyse uit. Vooreerst werd een basis- 
model gerund, waarin de interviewschaal fungeerde als afhankelijke variabele en de leeftijd van de jobkandidaten, de verschillende andere kenmerken van de jobkandidaten (bijv. het geslacht en extra-curriculaire activiteiten), de kenmerken van de participanten (bijv. geslacht, leeftijd en ervaring in werving en selectie) en de kenmerken van de jobs (bijv. de mate van fysieke inspanning en technologische knowhow geassocieerd met de baan) als onafhankelijke variabelen fungeerden (Tabel 5 , Kolom 1). Vervolgens voegden we verschillende interactietermen toe aan de regressie-analyse. Deze bestonden uit combinaties van de leeftijd van de jobkandidaat met de verschillende participant- en jobkarakteristieken (Tabel 5, Kolom 2, 3, 4 en 5). De resultaten van deze analyse kunnen worden gevonden in Tabel 5.

In Tabel 5 (Kolom 1) presenteren we eerst de resultaten van het gerunde basismodel. We vonden (sterk) significante effecten van alle kandidaat-karakteristieken op de kans om uitgenodigd te worden voor een jobinterview, met uitzondering van het geslacht van de kandidaat en het doen van culturele activiteiten als extra-curriculaire activiteiten. Meer concreet vonden we naast het reeds besproken negatieve leeftijdseffect (zie 3.1 en 3.2) een positief effect van (1) een korte afstand tussen de woonplaats en de plaats van tewerkstelling, (2) het hebben van twee tot tien jaar ervaring in het beroep en (3) het doen van vrijwilligerswerk of sportactiviteiten op de kans om uitgenodigd te worden voor een jobinterview. Daarnaast vonden we dat participanten die tewerkgesteld zijn in een bedrijf met een hoog percentage aan oudere werknemers, hogere scores gaven op de interviewschaal in vergelijking met participanten die tewerkgesteld zijn in een bedrijf waar minder oudere werknemers werkzaam zijn. Bovendien vonden we dat de kansen om uitgenodigd te worden voor een interview lager liggen in jobs waar een hoog niveau van algemene vaardigheden vereist was. Dit negatieve effect was echter slechts significant op het 10\%-significantieniveau. We kunnen dus niet uitsluiten dat dit resultaat per toeval gevonden werd.

In Kolom 2, 3 en 4 van Tabel 5 presenteren we vervolgens de resultaten van hetzelfde basismodel waaraan verschillende interactietermen tussen de leeftijd van de jobkandidaten en de verschillende participant- en job-karakteristieken werden toegevoegd. In het tweede model namen we, ten eerste, ook de interactietermen tussen de leeftijd van de jobkandidaten en de participant-karakteristieken op. We vonden hier geen significante interactie-effecten. In Kolom 3 en 4 van Tabel 5 staan de resultaten van de analyses waarin ook de interactietermen werden toegevoegd tussen de leeftijd van de kandidaten en (1) de vier job-karakteristieken en (2) de zeven afzonderlijke beroepen, respectievelijk. Hieruit blijkt dat oudere jobkandidaten minder worden aangeworven voor jobs waarvoor grote fysieke inspanningen vereist zijn. Dit negatieve interactie-effect is echter zwak significant (d.w.z. op het 10\%-significantieniveau). We kunnen dus wederom niet uitsluiten dat we dit resultaat per toeval gevonden hebben. Daarnaast identificeerden we (zwak) significante negatieve interactie-effecten tussen de leeftijd van de jobkandidaten en alle beroepen, met uitzondering van het beroep van installateur van plaatbewerkingsmachines.

In Kolom (5) van Tabel 5 presenteren we, tot slot, de resultaten van het basismodel waaraan zowel de interactie-termen inzake de participant-karakteristieken als 


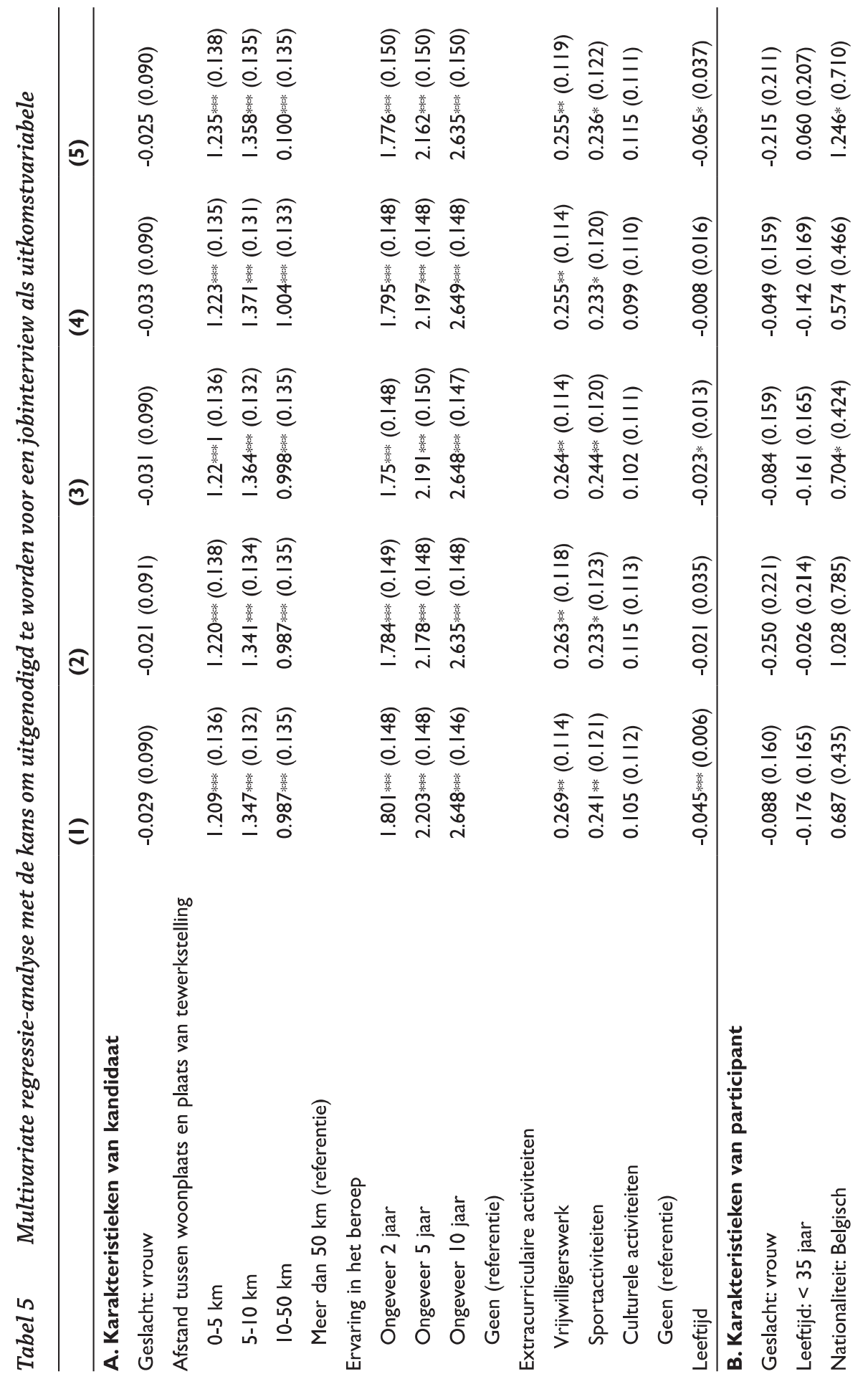




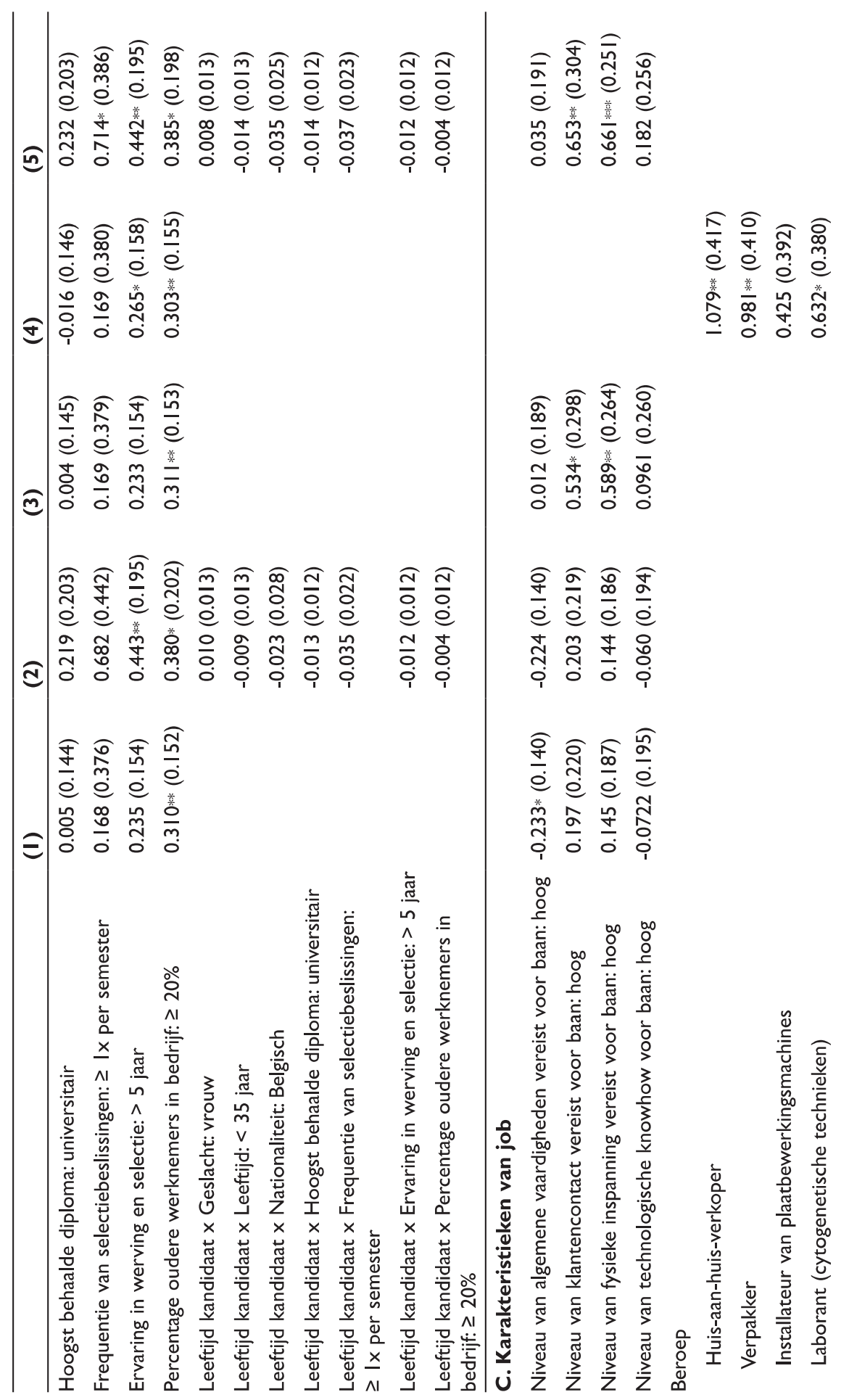




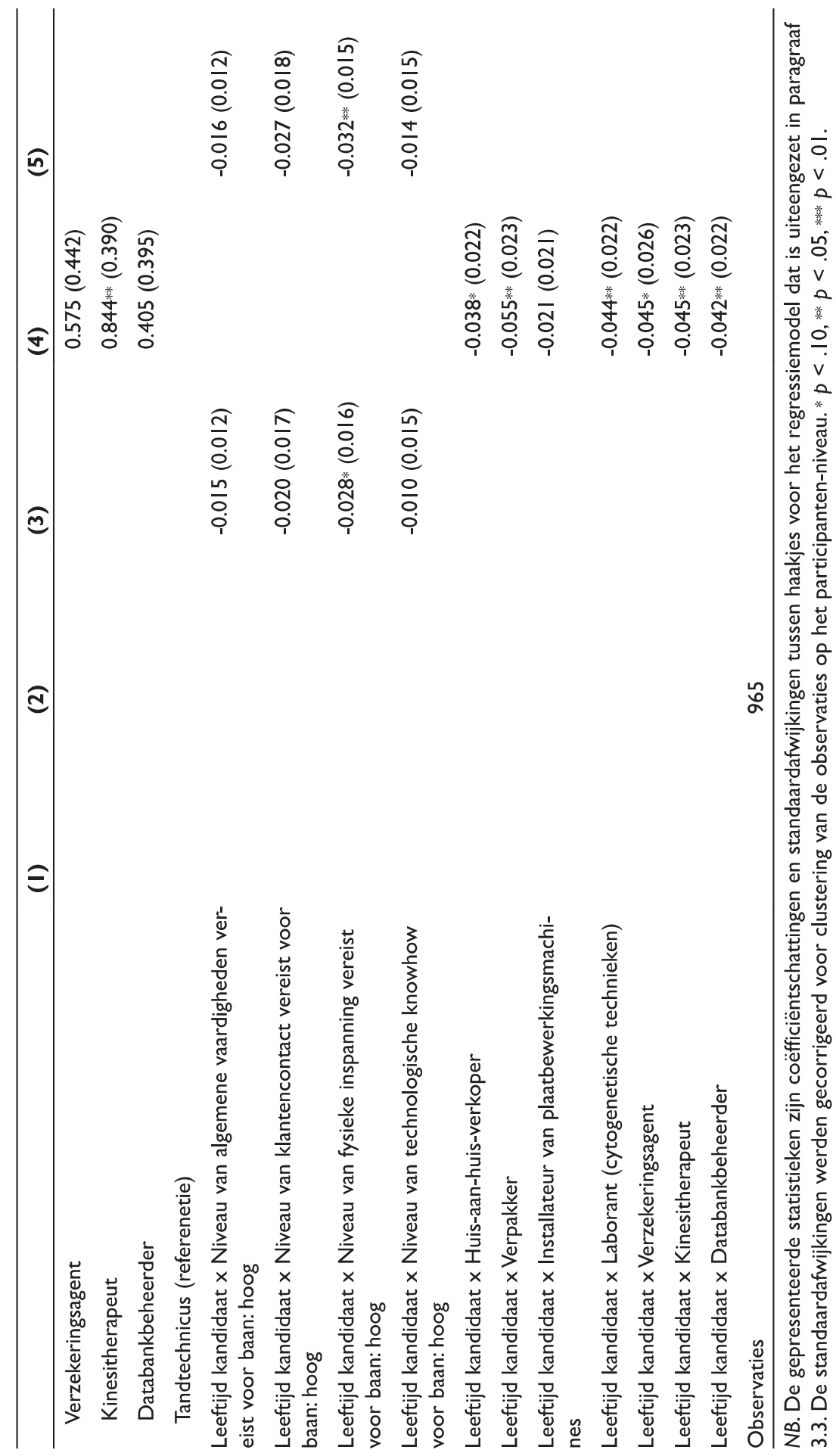


deze inzake de job-karakteristieken werden toegevoegd. De resultaten komen sterk overeen met de resultaten gepresenteerd in Kolom (2) en (3). Het zwak significante interactie-effect dat we vonden tussen de leeftijd van de jobkandidaten en de jobs waarvoor fysieke inspanningen vereist zijn in het derde model, vinden we hier ook weer terug. Het is nu echter significant op $5 \%$-significantieniveau. We kunnen derhalve concluderen dat oudere jobkandidaten sterker worden gediscrimineerd wanneer zij solliciteren voor jobs die veel fysieke inspanning vereisen in vergelijking met jobs waarvoor dit niet het geval is.

\section{Discussie}

In deze studie zetten we de volgende logische stap in de studie naar leeftijdsdiscriminatie op de Vlaamse arbeidsmarkt. Daar waar vorige studies vooral inzetten op het meten van discriminatie jegens 50-plussers in het selectieproces, focussen wij op het blootleggen van de mechanismen en moderatoren onderliggend aan deze problematiek, wat cruciaal is voor het kunnen uitrollen van een adequaat beleid ter zake. Hiervoor voerden we een vignettenexperiment uit bij 193 Vlaamse HR-professionals. We vonden dat, volgens de HR-professionals, een oudere leeftijd op iemands cv (1) lagere fysieke capaciteiten, (2) lagere technologische kennis en vaardigheden, (3) een lagere flexibiliteit en (4) een lagere trainbaarheid suggereerde. Tegelijk werd voor oudere jobkandidaten (5) een hogere mate van gepercipieerde betrouwbaarheid gevonden. Daarnaast vonden we ook dat een oudere leeftijd gerelateerd was aan een lagere (gepercipieerde) bereidheid bij (6) recruiters en (7) werknemers om samen te werken. Daar technologische kennis en vaardigheden enerzijds en flexibiliteit anderzijds ook sterk bleken samen te hangen met de beslissing een kandidaat al dan niet uit te nodigen voor een jobgesprek, verklaarden stigma's aangaande deze kwaliteiten in belangrijke mate de ongunstige behandeling van oudere kandidaten in ons experiment. Daarnaast vonden we dat oudere jobkandidaten in sterkere mate werden gediscrimineerd in jobs waarvoor veel fysieke inspanningen vereist zijn.

Onze resultaten voor Vlaamse HR-professionals liggen derhalve grotendeels in lijn met die van Van Borm et al. (2019), waarin op grotere, internationale schaal een heel gelijkaardig experiment werd uitgevoerd met voornamelijk Amerikaanse individuen met ervaring in werving en selectie en waarvoor deze studie als voorstudie fungeerde. Concreet vonden Van Borm et al. (2019) eveneens bewijs voor statistische discriminatie, waarbij de percepties omtrent de technologische kennis en vaardigheden, flexibiliteit en trainbaarheid van oudere werknemers fungeren als voornaamste verklaringen. In hun studie werd evenwel ook het stigma van hogere loonkosten voor oudere werknemers opgenomen. Ook voor dat stigma werd er een beperkte mediërende rol gevonden tussen de leeftijd van de jobkandidaten en diens aanstellingskansen. Anderzijds werd de positieve impact van een hogere leeftijd op de gepercipieerde betrouwbaarheid van een kandidaat niet teruggevonden in Van Borm et al. (2019). Inzake de moderatie-effecten van de verschillende participanten en job-karakteristieken vonden we andere resultaten. Meer concreet identificeerden Van Borm et al. (2019) dat participanten die tewerkgesteld zijn in een bedrijf waar veel oudere werknemers werkzaam zijn, in mindere mate discrimineren jegens 
oudere jobkandidaten in vergelijking met participanten die tewerkgesteld zijn in een bedrijf waar minder oudere werknemers werken. Daarnaast vonden zij ook dat oudere jobkandidaten sterker werden gediscrimineerd in jobs waarvoor een hoog niveau van algemene vaardigheden vereist is. Het negatieve interactie-effect tussen de leeftijd van de jobkandidaten en de beroepen waarvoor veel fysieke inspanning vereist is, dat werd gevonden in deze studie, vonden zij echter niet terug.

Ondanks dat deze studie veel te bieden heeft op zowel academisch als maatschappelijk vlak, heeft ze ook een aantal beperkingen. Ten eerste kan aan de gevonden mediatie-effecten geen causale interpretatie worden gegeven. Terwijl aan de geschatte effecten van de leeftijd van de fictieve jobkandidaten op de verschillende perceptie- en attitudeschalen wel een causale interpretatie kan worden gegeven, geldt dat niet voor de associatie tussen deze verschillende schalen en de interviewen aanstellingsschaal. Om dit mogelijk te maken zouden de verschillende perceptie- en attitudeschalen ook experimenteel dienen te worden gemanipuleerd. Dit was echter niet mogelijk binnen de context van het huidige onderzoek. Toekomstig onderzoek zou daarom moeten focussen op de experimentele manipulatie van de verschillende leeftijdssignalen om zo causale effecten van de percepties en attituden van wervingsprofessionals jegens oudere jobkandidaten op de tewerkstellingskansen van deze kandidaten te identificeren.

Ten tweede is onze studie beperkt door haar onderzoekssetting. In laboratoriumexperimenten zoals het onze zijn de participanten zich er namelijk van bewust dat ze deelnemen aan een experiment en dienen ze beslissingen te maken aangaande fictieve beschrijvingen of situaties. Dit brengt met zich mee dat de participanten mogelijk op een sociaal wenselijke manier zullen antwoorden of zich mogelijk anders zullen gedragen dan zij in werkelijkheid zouden doen. Dit kan de resultaten hebben vertekend. Deze vertekeningen lijken echter een minder grote rol te spelen bij vignettenexperimenten, en in het bijzonder in dit vignettenexperiment, omdat we (1) werkten met echte HR-managers en (2) de verschillende kandidaat-karakteristieken gelijktijdig manipuleerden en we dus de complexe aard van een aanstellingsbeslissing zo goed mogelijk nabootsten. Voorgaand onderzoek heeft inderdaad aangetoond dat de beslissingen gemaakt in een vignettenexperiment sterk gecorreleerd zijn met eigenlijk gedrag (Baert \& De Pauw, 2014; Hainmueller, Hangartner, \& Yamamoto, 2015; Van Belle et al., 2018). Door de participanten een beperkt aantal vignetten te laten evalueren waarin verschillende kandidaat-karakteristieken gelijktijdig werden gevarieerd, is het daarnaast heel moeilijk voor de participanten om sociaal wenselijke antwoorden te identificeren (Auspurg \& Hinz, 2014; Mutz, 2011). Ten derde zijn de resultaten van ons onderzoek moeilijk te generaliseren naar andere contexten. Een van de kenmerken eigen aan laboratoriumexperimenten is dat er doorgaans één beperkte (fictieve) setting bestudeerd wordt, waardoor het moeilijk is te weten of de relaties die gevonden worden in de experimentele context ook gevonden worden in andere contexten. In ons onderzoek beoogden we de generaliseerbaarheid van onze resultaten te verhogen door (1) de jobkandidaten te laten variëren over vijf verschillende kenmerken en (2) acht zeer uiteenliggende vacatures uit verschillende sectoren in acht te nemen. We kunnen echter niet uitsluiten dat de resultaten anders uitpakken, wanneer men het onderzoek uitrolt in een ander land, en wanneer men andere kandidaat-karakteristieken en andere vacatures in 
acht neemt. De stigma's gerelateerd aan een oudere leeftijd kunnen namelijk verschillen voor subgroepen van oudere jobkandidaten, in verschillende typen van jobs of in verschillende landen. Toekomstig onderzoek is derhalve nodig om de prevalentie van de verschillende leeftijdsstigma's jegens verschillende subgroepen van oudere jobkandidaten (zie bijv. Lahey \& Oxley, 2018) en in uiteenlopende contexten en landen na te gaan (zie bijv. Cuddy, Norton, \& Fiske, 2005).

Tot slot concentreerden we ons in deze studie enkel op mogelijke verklaringen aangehaald in de economische literatuur. In andere disciplines worden echter ook interessante verklaringen aangehaald voor discriminatie in het wervings- en selectieproces. Denk hierbij bijvoorbeeld aan het 'stereotype-content-model' van Cuddy, Fiske en Glick (2008) en het idee van impliciete discriminatie (Bertrand, Chugh, \& Mullainathan, 2005). Toekomstig onderzoek zou derhalve ook deze verklaringen kunnen meenemen in studies naar de achterliggende mechanismen en moderatoren van leeftijdsdiscriminatie in het wervings- en selectieproces.

\section{Praktijkbox}

Wat betekenen de resultaten voor de praktijk?

- Ondanks de uitgebreide anti-discriminatiewetgeving in België vinden we een evidentie voor leeftijdsdiscriminatie in het wervings- en selectieproces. Beleidsmakers zouden dan ook moeten investeren in een actieve detectie van arbeidsmarktdiscriminatie om deze problematiek aan te pakken. Veldexperimenten zoals deze van Baert et al. (2016) kunnen hiervoor als tool gebruikt worden.

- We vinden dat leeftijdsdiscriminatie in het selectieproces wordt gedreven door negatieve stereotypen omtrent de productiviteit van oudere jobkandidaten. Om tegen te gaan dat werkgevers zich baseren op stereotypen bij het maken van selectiebeslissingen, dienen beleidsmakers te investeren in bewustwordingscampagnes die werkgevers en HR-professionals bewust maken van mogelijke stereotypen en stigma's en tegenvoorbeelden in de kijker zetten. Daarnaast zouden beleidsmakers bedrijven en organisaties moeten aanmoedigen om zelf te investeren in bewustwordingscampagnes en diversiteitsmanagement door er een (al dan niet financiële) beloning tegenover te stellen.

- Om tegen te gaan dat recruiters zich baseren op stereotypen bij het maken van selectiebeslissingen, is ook een belangrijke rol voor de sollicitanten zelf weggelegd. Sollicitanten dienen werkgevers en HR-professionals voldoende informatie te verschaffen omtrent hun technologische kennis en vaardigheden, flexibiliteit, relevante werkervaring en trainbaarheid, om de stereotypen die bestaan proactief te weerleggen.

- We vinden dat de perceptie van recruiters omtrent de technologische kennis en vaardigheden van oudere jobkandidaten een van de voornaamste verklaringen is voor leeftijdsdiscriminatie in het selectieproces. Om het vermeende verschil in technologische knowhow tussen oudere en jongere jobkandidaten te verkleinen zouden beleidsmakers moeten investeren in trainingsprogramma's gefocust op het aanleren 
van technologische kennis en vaardigheden en specifiek (maar niet alleen) gericht aan oudere jobkandidaten.

\section{Noten}

1 De D-efficiëntie van een experimenteel design is voldoende hoog wanneer het de grenswaarde van 0.90 overschrijdt. Voor een meer gedetailleerde en technische discussie van het D-efficiënt design verwijzen we ook graag naar Auspurg en Hinz (2014), Kuhfeld (2010) en Kuhfeld, Tobias en Garratt (1994).

2 O*Net is een online database ontwikkeld door het Amerikaanse ministerie van arbeid waarin informatie omtrent de jobinhoud en de kenmerken vereist om de job naar behoren uit te voeren van meer dan 1000 verschillende beroepen wordt beschreven.

3 Uiteindelijk kregen 26 participanten de vacature van tandtechnicus gepresenteerd, 22 de vacature van huis-aan-huis-verkoper, 27 de vacature van verpakker, 21 de vacature van installateur van plaatbewerkingsmachines, 24 de vacature van laborant (cytogenetische technieken), 21 de vacature van verzekeringsagent, 30 de vacature van kinesitherapeut en 22 de vacature van databankbeheerder.

4 Merk op dat deze twee deel-effecten overeenkomen met de twee stappen die zijn besproken bij de bivariate analyse. Net zoals bij de bivariate analyse kunnen we het effect van de leeftijd van de jobkandidaten op de verschillende kandidaat-evaluatiescores een causale interpretatie geven, maar kunnen we dit niet voor het effect van de perceptie- en attitudeschalen op de tewerkstellingskansen van de jobkandidaten. Deze schalen worden namelijk niet experimenteel gemanipuleerd, waardoor het mogelijk is dat de verschillende percepties en attituden nog gecorreleerd kunnen zijn met niet-geobserveerde vooroordelen.

5 Op het eerste gezicht lijkt het vreemd dat het negatieve leeftijdseffect op de selectiekansen van de jobkandidaten verklaard wordt door de perceptie dat oudere jobkandidaten minder ervaring zouden hebben. Hierbij moet echter rekening worden gehouden met het feit dat de ervaring van de jobkandidaten conditioneel werd beoordeeld op hun ervaring in het beroep gereveleerd in de fictieve profielen. Daardoor kan het zijn dat een hogere leeftijd het negatieve signaal van vele jaren van irrelevante ervaring reflecteert (Baert et al., 2016) en als gevolg daarvan leidt tot een lagere score op de perceptieschaal omtrent de nodige ervaring om goed te presteren in de job.

\section{Literatuur}

AARP. (2000). American business and older employees. Washington, DC: AARP.

Allport, G. W. (1979). The nature of prejudice. Cambridge, MA: Perseus Books. Arrow, K. J. (1973). The theory of discrimination. In O. Ashenfelter \& A. Rees (Eds.), Discrimination in labor markets (pp. 3-33). Princeton, NJ: Princeton University Press. Auspurg, K., \& Hinz, T. (2014). Factorial survey experiments. Thousand Oaks, CA: Sage. 
Baert, S. (2018). Hiring discrimination: an overview of (almost) all correspondence experiments since 2005. In S.M. Gaddis (Ed.), Audit studies: Behind the scenes with theory, method, and nuance (pp. 63-77). Cham: Springer.

Baert, S. (2019). Jobs Jobs Jobs! Heeft Michel-I de mantra waar gemaakt? Mimeo.

Baert, S., \& De Pauw, A. S. (2014). Is ethnic discrimination due to distaste or statistics? Economics Letters, 125, 270-273.

Baert, S., Norga, J., Thuy, Y., \& Van Hecke, M. (2016). Getting grey hairs in the labour market: An alternative experiment on age discrimination. Journal of Economic Psychology, 57, 86-101.

Becker, G. S. (1957). The economics of discrimination. Chicago, IL: University of Chicago Press.

Bertrand, M., Chugh, D., \& Mullainathan, S. (2005). Implicit discrimination. American Economic Review, 95, 94-98.

Burn, I., Button, P., Corella, L.M., \& Neumark, D. (2019). Older workers need not to apply? Ageist language in job ads and age discrimination in hiring. NBER Working Paper, no. 26552.

Büsch, V., Dahl, S. A., \& Dittrich, D. A. (2009). An empirical study of age discrimination in Norway and Germany. Applied Economics, 41, 633-651.

Carlsson, M., \& Eriksson, S. (2019). Age discrimination in hiring decisions: Evidence from a field experiment in the labor market. Labour Economics, 59, 173-183.

Carlsson, M., Reshid, A. A., \& Rooth, D. O. (2018). Neighborhood signaling effects, commuting time, and employment: Evidence from a field experiment. International Journal of Manpower, 39, 534-549.

Cuddy, A. J., Fiske, S. T., \& Glick, P. (2008). Warmth and competence as universal dimensions of social perception: The stereotype content model and the BIAS map. Advances in Experimental Social Psychology, 40, 61-149.

Cuddy, A. J., Norton, M. I., \& Fiske, S. T. (2005). This old stereotype: The pervasiveness and persistence of the elderly stereotype. Journal of Social Issues, 61, 267-285.

De Callatay, E., \& Turtelboom, B. (1996). Pension reform in Belgium. IMF Working Paper, no. 96/74.

Federale Pensioendienst. (2019). Pensioenleeftijd (Werknemersstelsel). Retrieved from www. onprvp.fgov.be

Finkelstein, L. M., Burke, M. J., \& Raju, M. S. (1995). Age discrimination in simulated employment contexts: An integrative analysis. Journal of Applied Psychology, 80, 652-663.

Hainmueller, J., Hangartner, D., \& Yamamoto, T. (2015). Validating vignette and conjoint survey experiments against real-world behaviour. Proceedings of the National Academy of Sciences, 112, 2395-2400.

Hayes, A. F. (2013). Introduction to mediation, moderation, and conditional process analysis: A regression-based approach. New York, NY: Guilford Press.

Heckman, J., Pinto, R., \& Savelyev, P. ( 2013). Understanding the mechanisms through which an influential early childhood program boosted adult outcomes. American Economic Review, 103, 2052-2086. doi: 10.1257/aer.103.6.2052

Jasso, G. (2006). Factorial survey methods for studying beliefs and judgments. Sociological Methods and Research, 34, 334-42.

Jensen, P. H., De Tavernier, W. and Nielsen, P. (in press). To what extent are ageist attitudes among employers translated into discriminatory practices: The case of Denmark. International Journal of Manpower. ahead-of-print. https://doi.org/10.1108

Kuhfeld, W. F. (2010). Statistical graphics in SAS: An introduction to the graph template language and the statistical graphics procedures. SAS Publishing.

Kuhfeld, W. F., Tobias, R. D., \& Garratt, M. (1994). Efficient experimental design with marketing research applications. Journal of Marketing Research, 31, 545-557. 
Lahey, J. N., \& Oxley, D. R. (2018). Discrimination at the intersection of age, race, and gender: Evidence from a lab-in-the-field experiment. NBER Working Paper, no. w25357.

Macan, T. H., Detjen, J. B., \& Dickey, K. L. (1994). Measures of job perceptions: Gender and age of current incumbents, suitability, and job attributes. Sex Roles, 30, 55-67.

McCann, R. M., \& Keaton, S. A. (2013). A cross cultural investigation of age stereotypes and communication perceptions of older and younger workers in the USA and Thailand. Educational Gerontology, 39, 326-341.

Mutz, D. C. (2011). Population-based survey experiments. Princeton, NJ: Princeton University Press.

Neumark, D. (2018). Experimental research on labor market discrimination. Journal of Economic Literature, 56, 799-866.

Nuijten, M. P., Poell, R. F., \& Alfes, K. (2017). Extracurricular activities of Dutch university students and their effect on employment opportunities as perceived by both students and organizations. International Journal of Selection and Assessment, 25, 360-370.

Olian, J. D., Schwab, D. P., \& Haberfeld, Y. (1988). The impact of applicant gender compared to qualifications on hiring recommendations: A meta-analysis of experimental studies. Organizational Behavior and Human Decision Processes, 41, 180-195

Perry, E. L., \& Finkelstein, L. M. (1999). Toward a broader view of age discrimination in employment-related decisions: A joint consideration of organizational factors and cognitive processes. Human Resource Management Review, 9, 21-49.

Perry, E. L., Kulik, C. T., \& Bourhis, A. C. (1996). Moderating effects of personal and contextual factors in age discrimination. Journal of Applied Psychology, 81, 628-647.

Pestieau, P., \& Stijns, J. P. (1999). Social security and retirement in Belgium. In J. Gruber \& D. A. Wise (eds.), Social security and retirement around the world (pp. 37-71). University of Chicago Press.

Posthuma, R. A., \& Campion, M. A. (2009). Age stereotypes in the workplace: Common stereotypes, moderators, and future research directions. Journal of Management, 35, 158-188.

Richardson, B., Webb, J., Webber, L., \& Smith, K. (2013). Age discrimination in the evaluation of job applicants. Journal of Applied Social Psychology, 43, 35-44.

Rossi, P. H., \& Nock, S. L. (1982). Measuring social judgements: The factorial survey approach. Thousand Oaks, CA: Sage.

Sauer, C., Hinz, T., Auspurg, K., \& Liebig, S. (2011). The application of factorial surveys in general population samples: The effects of respondent age and education on response times and response consistency. Survey Research Methods, 5, 89-102.

Van Belle, E., Caers, R., Cuypers, L., De Couck, M., Neyt, B., Van Borm, H., \& Baert, S. (2020). What do student jobs on graduate CVs signal to employers? Economics of Education Review, 75, 101979.

Van Belle, E., Di Stasio, V., Caers, R., De Couck, M., \& Baert, S. (2018). Why are employers put off by long spells of unemployment? European Sociological Review, 34, 694-710.

Van Borm, H., \& Baert, S. (2018). What drives hiring discrimination against transgenders? International Journal of Manpower, 39, 581-599.

Van Borm, H., Burn, I., \& Baert, S. (2019). What does a job candidate's age signal to employers? IZA Discussion Paper Series, no. 12849.

Van Borm, H., Dhoop, M., Van Acker, A., \& Baert, S. (in press). What does someone's gender identity signal to employers? International Journal of Manpower.

Van Dalen, H. P., Henkens, K., \& Schippers, J. (2009). Dealing with older workers in Europe: A comparative survey of employers' attitudes and actions. Journal of European Social Policy, 19, 47-60.

Warr, P., \& Pennington, J. (1993). Views about age discrimination and older workers. In Age and employment: Policies, attitudes, and practices (pp. 75-106). London: Institute of Personnel Management. 


\section{Bijlagen}

Tabel A.1 Gebruikte vignettenfactoren en bijhorende vignettenniveaus in het experimenteel materiaal

\begin{tabular}{ll}
\hline Vignettenfactoren & Vignettenniveaus \\
\hline Geslacht & $\{$ Man,Vrouw $\}$ \\
Leeftijd & $\{32,33,34,35,36, \ldots, 63\}$ \\
Afstand tussen woonplaats en plaats van & $\{0-5 \mathrm{~km}, 5-10 \mathrm{~km}, 10-50 \mathrm{~km}$, Meer dan \\
tewerkstelling & $50 \mathrm{~km}\}$ \\
Ervaring in het beroep & $\{$ Geen, Ongeveer 2 jaar, Ongeveer 5 jaar, \\
& Ongeveer I0 jaar \\
Extra-curriculaire activiteiten & $\{$ Geen,Vrijwilligerswerk, Sportactiviteiten, \\
& Culturele activiteiten $\}$ \\
\hline
\end{tabular}

NB. Zoals beschreven in paragraaf 2 werden er in totaal 200 profielen (d.w.z. verschillende combinaties van vignettenniveaus) geselecteerd en systematisch gegroepeerd in 40 decks van vijf profielen. Deze 40 decks werden vervolgens lukraak (random) verdeeld over de participanten.

Tabel A.2 Voorbeeldprofiel van een fictieve jobkandidaat, zoals gepresenteerd aan de participanten

\section{Profiel Kandidaat A}

Geslacht Man

Leeftijd

43

Afstand tussen woonplaats en plaats van tewerkstelling

Ervaring in het beroep

Ongeveer 5 jaar

Extra-curriculaire activiteiten

Vrijwilligerswerk

NB. In Tabel A.2 presenteren we een voorbeeld van één van de 200 profielen die zijn gebruikt in het experimenteel design en zijn besproken in paragraaf 2.

Tabel A.3 Gebruikte stellingen in het experimenteel materiaal

\begin{tabular}{|c|c|}
\hline Kandidaat-evaluatiescores & Stellingen \\
\hline \multicolumn{2}{|l|}{ A. Interview- en aanstellingsschaal } \\
\hline Kans om uitgenodigd te worden voor interview & $\begin{array}{l}\text { 'Ik zal de kandidaat uitnodigen voor een solli- } \\
\text { citatiegesprek bij Franssen NV voor de } \\
\text { omschreven functie.' }\end{array}$ \\
\hline Kans om aangesteld te worden & $\begin{array}{l}\text { 'Er is een grote kans dat ik de kandidaat ook } \\
\text { effectief zal aanstellen voor de functie bij } \\
\text { Franssen NV.' }\end{array}$ \\
\hline
\end{tabular}




\section{Kandidaat-evaluatiescores}

\section{B. Perceptieschalen}

Veronderstelde mentale capaciteiten

Veronderstelde sociale capaciteiten

Veronderstelde fysieke capaciteiten

Veronderstelde technologische kennis en skills

Veronderstelde flexibiliteit

Veronderstelde creativiteit

Veronderstelde ervaring

Veronderstelde motivatie

Veronderstelde betrouwbaarheid

Veronderstelde nauwkeurigheid

Veronderstelde trainbaarheid

C.Attitudeschalen

Bereidheid van participant om samen te werken ' $\mathrm{k}$ denk graag te zullen samenwerken met

Bereidheid van werknemers om samen te werken

Bereidheid van klanten om samen te werken deze persoon.'

'Ik denk dat andere werknemers graag zullen samenwerken met deze persoon.'

'Ik denk dat deze persoon over voldoende intellectuele capaciteiten beschikt om naar behoren te presteren in deze job.'

' $\mathrm{k}$ denk dat deze persoon over voldoende sociale capaciteiten beschikt om naar behoren te presteren in deze job.'

'lk denk dat deze persoon over voldoende fysieke capaciteiten beschikt om naar behoren te presteren in deze job.'

' $\mathrm{k}$ denk dat deze persoon over voldoende technologische kennis en vaardigheden beschikt om naar behoren te presteren in deze job.'

'lk denk dat deze persoon over voldoende flexibiliteit beschikt om naar behoren te presteren in deze job.'

'Ik denk dat deze persoon over voldoende creativiteit beschikt om naar behoren te presteren in deze job.'

'lk denk dat deze persoon over voldoende ervaring beschikt om naar behoren te presteren in deze job.'

'Ik denk dat deze persoon voldoende gemotiveerd zal zijn om naar behoren te presteren in deze job.'

'Ik denk dat deze persoon voldoende betrouwbaar zal zijn om naar behoren te presteren in deze job.'

'Ik denk dat deze persoon voldoende nauwkeurig zal zijn om naar behoren te presteren in deze job.'

'lk denk dat deze persoon voldoende gemakkelijk zaken zal aanleren om naar behoren te presteren in deze job.'

'Ik denk dat klanten graag zullen samenwerken met deze persoon.'

NB. Zoals aangehaald in paragraaf 2 presenteren we de verschillende kandidaat-evaluatiescores en bijhorende stellingen die opgenomen werden in de online survey. 
Tabel A.4 Meervoudige mediatie-analyse

\begin{tabular}{lll}
\hline Interviewschaal & Aanstellingsschaal \\
\hline$(1)$ & $(2)$ \\
\hline \% van totale & p-waarde & \% van totale $\quad$-waarde \\
leeftijdseffect & leeftijdseffect \\
verklaard door & verklaard door & \\
mediator & mediator & \\
\hline
\end{tabular}

\section{A. Perceptieschalen}

Veronderstelde mentale capa-

$0 \%$

[0.740]

$1 \%$

$[0.583]$

citeiten

Veronderstelde sociale capaci-

$0 \%$

$[0.820]$

$-1 \%$

teiten

Veronderstelde fysieke capaci-

$4 \%$

$4 \%$

teiten

Veronderstelde technologische

$4 \%$

[0.095]

$4 \%$

nis en skills

Veronderstelde flexibiliteit

$4 \%$

[0.08I]

$6 \%$

Veronderstelde creativiteit

Veronderstelde ervaring

Veronderstelde motivatie

Veronderstelde betrouwbaar-

heid

Veronderstelde nauwkeurig-

Veronderstelde trainbaarheid $3 \%$

\section{B.Attitudeschalen}

Bereidheid van participant om

samen te werken

om samen te werken

Bereidheid van klanten om

$0 \%$

[0.873]

$0 \%$

[0.978]

samen te werken

NB. Zoals aangehaald in paragraaf 3.2 presenteren we de resultaten van het besproken mediatiemodel. In lijn met Heckman, Pinto en Savelyev (20l3) presenteren we de resultaten hier als percentages van het totale leeftijdseffect verklaard door de 14 mediatoren. Met andere woorden, we delen de verschillende indirecte effecten via de perceptie- en attiudeschalen op iemands aanstellingskansen door het totale (negatieve) effect van de leeftijd van de jobkandidaten. Bijgevolg dienen de percentages met een positief teken in Tabel A.4 te worden geïnterpreteerd als negatieve mediatie-effecten en dienen de percentages met een negatief teken te worden geïnterpreteerd als positieve mediatie-effecten. $p$-waarden zijn gecorrigeerd voor clustering van de observaties op het participanten-niveau. Percentages met een $p$-waarde kleiner dan . 10 zijn vetgedrukt. $N=965$ 


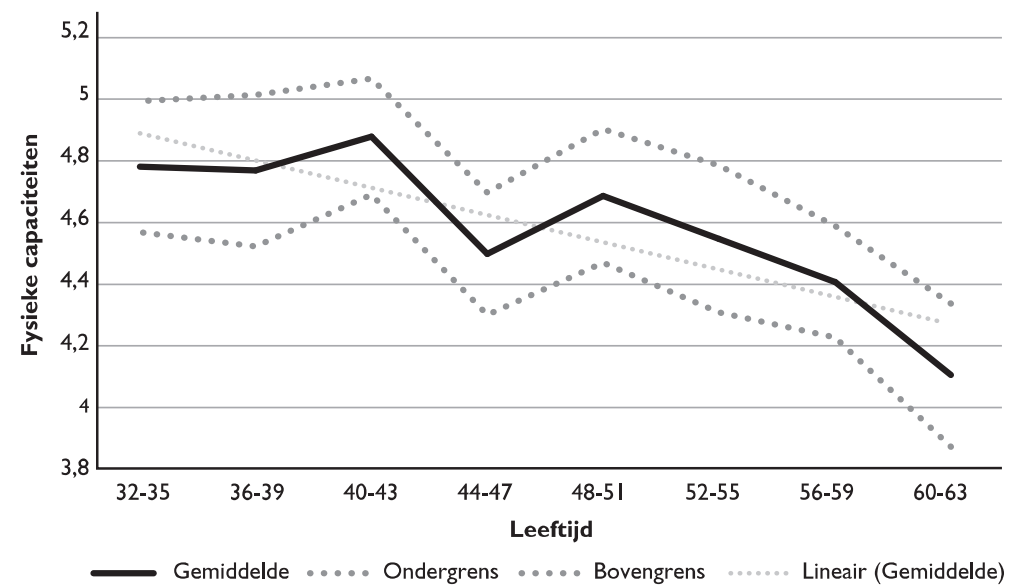

Figuur A.1 Veronderstelde fysieke capaciteiten per leeftijdscategorie NB. De grijze stippellijnen staan respectievelijk voor de onder- en bovengrens van het $95 \%$-betrouwbaarheidsinterval. De rechte stippellijn geeft de trendlijn van de gemiddelde scores weer.

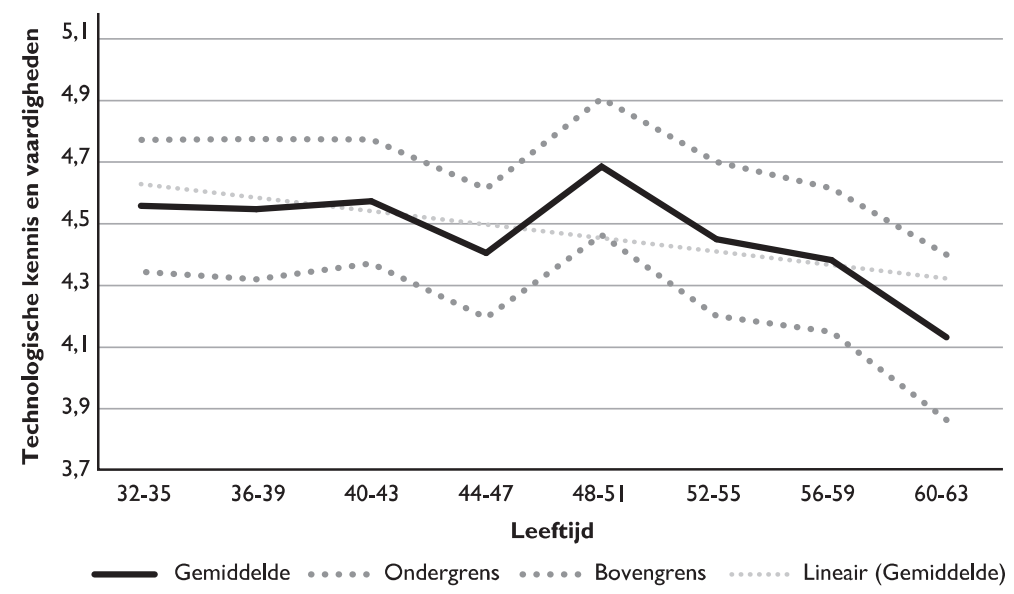

Figuur A.2 Veronderstelde technologische kennis en vaardigheden per leeftijdscategorie

NB. De grijze stippellijnen staan respectievelijk voor de onder- en bovengrens van het $95 \%$-betrouwbaarheidsinterval. De rechte stippellijn geeft de trendlijn van de gemiddelde scores weer. 


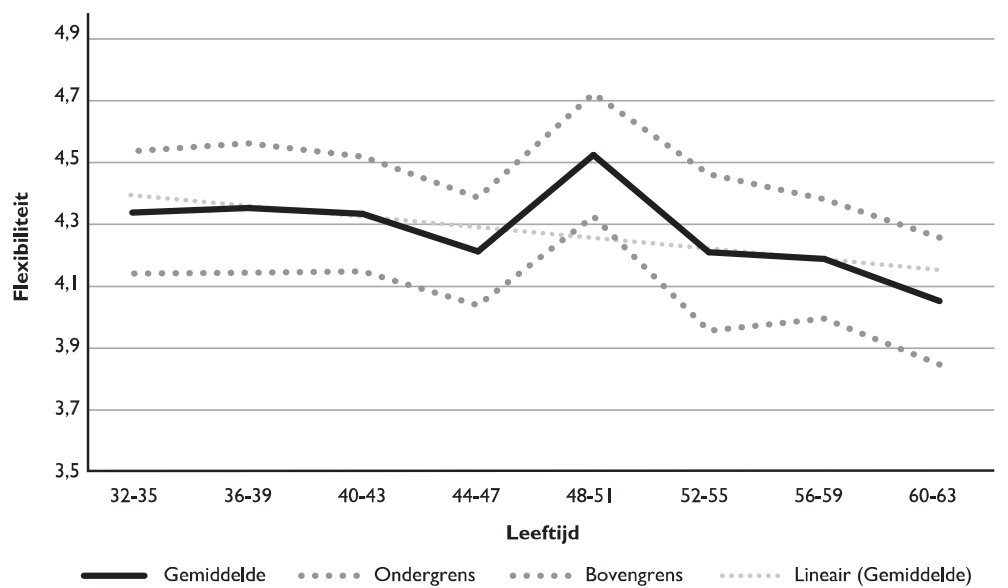

Figuur A.3 Veronderstelde flexibiliteit per leeftijdscategorie

$N B$. De grijze stippellijnen staan respectievelijk voor de onder-en bovengrens van het $95 \%$-betrouwbaarheidsinterval. De rechte stippellijn geeft de trendlijn van de gemiddelde scores weer.

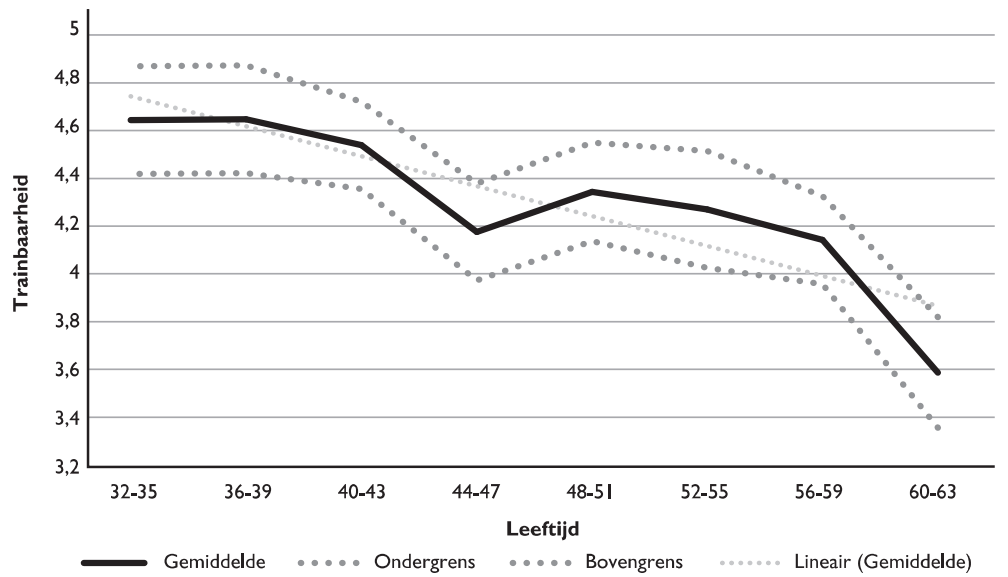

Figuur A.4 Veronderstelde trainbaarheid per leeftijdscategorie NB. De grijze stippellijnen staan respectievelijk voor de onder-en bovengrens van het $95 \%$-betrouwbaarheidsinterval. De rechte stippellijn geeft de trendlijn van de gemiddelde scores weer. 
Stigmas regarding the lower flexibility and technological knowledge of older job applicants lower their hiring chances

Van Borm, H., \& Baert, S. (2020), Gedrag \& Organisatie, volume 33, no. 3 pp. 209-242.

Research has shown that hiring discrimination towards older job applicants is a severe problem in Belgium. However, little is known about the reasons for this form of discrimination. In this study, we present a vignette experiment conducted among 193 Flemish HR professionals to empirically investigate which stereotypes and attitudes towards older job candidates explain age discrimination in hiring practices. Each participant assessed five fictitious job candidates on a number of characteristics. This resulted in 965 sets of observations. Our results indicate that recruiters associate an older age mentioned in a $\mathrm{CV}$ with lower physical capacities, less technological know-how, lower flexibility, lower trainability and a higher degree of reliability. Additionally, recruiters presume that other employees will be less inclined to collaborate with older job candidates. Of these different age signals, the perceptions of flexibility and technological know-how serve as the main explanations for the negative effect of one's age on one's hiring opportunities. Furthermore, we find that discrimination is more severe in jobs that are associated with high physical effort. This study is socially relevant since the effectiveness of anti-discrimination policies depends on the extent to which these policies respond to the mechanisms and moderators underlying discrimination.

Keywords: hiring, statistical discrimination, age, stereotypes 